\title{
STRENGTHENING HERITAGE TUNNELS TO ENHANCE THE RESILIENCE OF WELLINGTON'S TRANSPORT NETWORK
}

\section{Eleni Gkeli' ${ }^{1}$, Pathmanathan Brabhaharan ${ }^{2}$, Dejan Novakov ${ }^{3}$, Siva Arumugam ${ }^{4}$ and Gunasekaran Mookaiya ${ }^{5}$}

(Submitted October 2020; Reviewed December 2020; Accepted April 2021)

\begin{abstract}
Wellington city is characterised by steep hilly terrain, and as such several tunnels have been constructed since the beginning of the last century to provide critical transport access in the city. These tunnels are still used today as part of the city's transport routes, while also being an integral part of the city's history and heritage.

Wellington is among the most seismically active areas in New Zealand. Three major active faults located within the Wellington Region and the proximity to the subduction zone are the main contributors to the high seismicity. The aging tunnels were designed and constructed prior to the advent of earthquake design standards and are subject to deterioration. Hence, they require maintenance and strengthening to ensure operational integrity and resilience to earthquake and other hazard events. Authorities have been supported by the authors in managing the risk through identifying key vulnerabilities, and prioritisation and implementation of strengthening measures. Best practice investigation and strengthening techniques have been applied through the process to ensure resilience and cost effectiveness.

The paper presents case histories that highlight the value of investigations and assessment in understanding the risks, and novel strengthening measures developed to enhance resilience while preserving the heritage of the tunnels. Case histories include the seismic strengthening of the Hataitai Bus Tunnel, the Northland and Seatoun road tunnels and the investigation and assessment of the iconic Wellington Cable Car tunnels.
\end{abstract}

\section{INTRODUCTION}

The performance of transportation networks in earthquakes and their ability to continue to function for the benefit of society has been receiving increased attention in New Zealand. Wellington Region is characterised by rugged terrain and, as a result, tunnels are common and an integral part of important lifeline infrastructure. Most of these tunnel structures were constructed in the early 1900 s, before the development of seismic design standards, and are subject to aging and deterioration. Therefore, seismic assessment and upgrade help extend their operational lives and enhance resilience to earthquake and other hazards.

\section{RESILIENCE OF WELLINGTON'S TRANSPORT NETWORK}

Geology, Geomorphology and Seismotectonic Environment

New Zealand is a tectonically very active land mass due to its position at the boundary between the Pacific and Australian plates. The relative plate motion is expressed in New Zealand by the presence of numerous active faults, a high rate of smallto-moderate (magnitude $\mathrm{M}<7$ ) earthquakes, many large earthquakes and one great earthquake in historic times [1]. Two subduction zones, one at southwestern South Island (Fiordland subduction zone) and one at the eastern North Island (Hikurangi subduction zone) are linked by a 1000-km-long zone of dextral oblique slip faults (axial tectonic belt). Essentially all the relative plate motion is accommodated by the faults of the axial tectonic belt in the area between the Fiordland and Hikurangi subduction zones, see Figure 1.

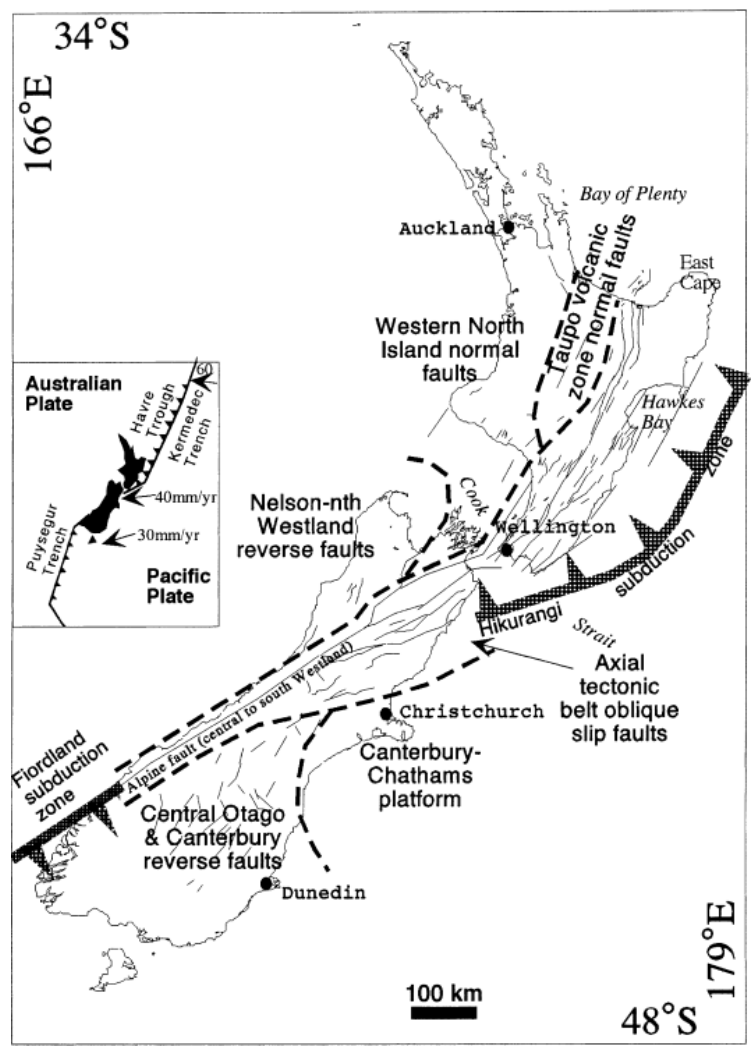

Figure 1: Plate tectonic setting of New Zealand [1].

\footnotetext{
1 Corresponding Author, Service Line Leader Engineering Geology, WSP New Zealand, Wellington, eleni.gkeli@wsp.com

2 National Technical Director, Geotechnical Engineering and Resilience, WSP New Zealand, Wellington (Fellow)

3 Technical Principal Civil Structures, WSP New Zealand, Wellington (Member)

4 Senior Geotechnical Engineer, WSP New Zealand, Wellington (Member)

5 Senior Geotechnical Engineer, WSP New Zealand, Wellington (Member)
} 
The Wellington Region is one of the most seismically active areas in New Zealand. The active faults located within the region, such as the Wellington, Ohariu and the Wairarapa faults, as well as the proximity to the subduction zone are the main contributors to the high seismicity (Figure 2).

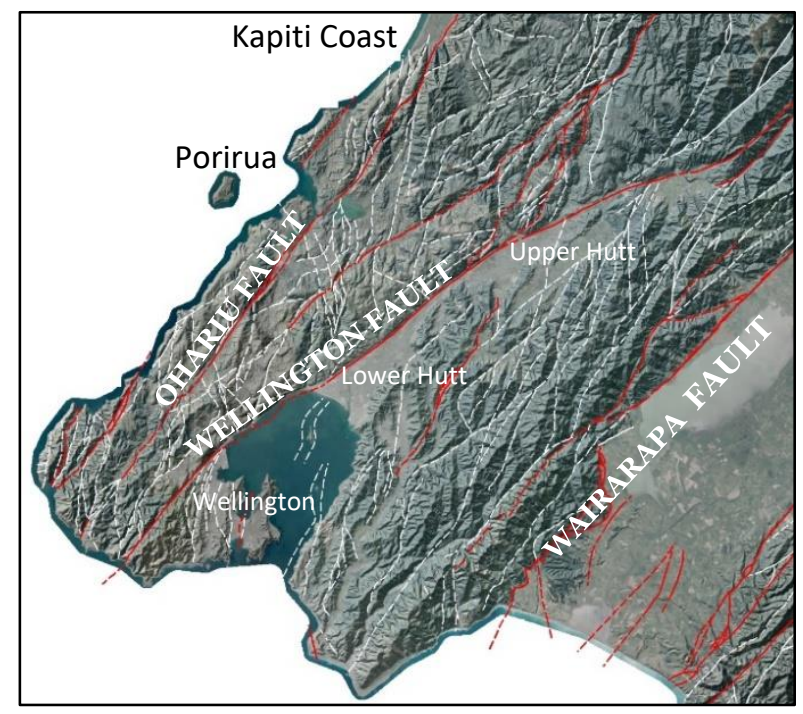

Figure 2: Active faults in the Wellington region.

The region is underlain by a rock complex commonly known as Wellington Greywacke, consisting of sandstone, siltstone, mudstone (argillite) and localised volcanic rocks. The rocks are metamorphosed, highly deformed and variably weathered, often with a high degree of fracturing and shearing [2]. The Wellington Region is also characterised by rugged terrain.

Urban infrastructure development in this terrain requires important transport routes to be associated with high cut slopes, retaining walls and tunnel structures. The active tectonic environment, the steep rugged terrain and tectonically deformed and fractured rocks contribute to the vulnerability of transport infrastructure in a variety of natural hazards such as storms, landslides, and earthquakes. The vulnerability of transportation networks in similar terrain has been distinctively demonstrated in the 14 November 2016 M7.8 Kaikoura earthquake event, where significant cut slope failures, landslides, and damage to tunnels and other structures caused one of the primary roads and railway corridors in New Zealand to remain closed for many months, while significant and costly remediation measures were required to restore access and functionality.

\section{Road Network Resilience Context in Wellington City}

Studies of the resilience of transportation networks of the Wellington Region started in the early 90s, with the Wellington
Engineering Lifelines study [3]. This study assessed the vulnerability of the Wellington Region's transport system to a major earthquake scenario (a magnitude M7.5 Wellington Fault event) and identified sections of the routes at high risk.

In 2001-2006, New Zealand research into strategies to manage the natural hazards risks to road networks led to the development of the concept of resilience for roads, together with metrics to measure resilience, using a geospatial platform [4]. A parallel study of the resilience of the Wellington City road network was carried out for Wellington City Council [5].

The key conclusion of the resilience studies for Wellington City is that access in and out of the city, as well as between suburbs within the city, will be closed in the event of a large earthquake by landslides and slope failures, as well as failures of structures, such as retaining walls, bridges and tunnels. The closures are expected to be for several months. Given the terrain, many of the routes in Wellington lack redundancy, and therefore response and recovery after an event will be severely jeopardised. The resilience issues associated with existing infrastructure assets would therefore need to be addressed.

\section{WELLINGTON CITY TRANSPORTATION TUNNELS}

Wellington City Council developed a strategy to enhance the resilience of the road network and since 2001 has been implementing a targeted long-term programme of strengthening important assets in its urban transport network [4,5]. The authors assisted the Council to assess the resilience of their assets and to develop the strengthening strategy, and have continued to assist in the implementation of strengthening works.

Part of this program were the four tunnels owned by Wellington City Council, Hataitai, Karori, Northland and Seatoun. These tunnels provide access between its key suburbs through Wellington's hilly terrain and were assessed as critical structures. This paper presents the investigation, assessment and strengthening of the Hataitai, Northland and Seatoun tunnels. Details of these tunnels are shown in Table 1.

In addition, the seismic assessment and development of strengthening concepts for the tunnels along the Wellington Cable Car line are also presented in this paper (see Table 1). The Cable Car is not a major transportation route, but consists an iconic historical feature of Wellington City, a tourist attraction, and provides ease of direct public transport up the hill to Kelburn from the central business district. The line is operated by the Wellington Cable Car Company, which is a council-controlled organisation (CCO) owned by Wellington City Council. The company is investing in the assessment of seismic performance, upgrading and maintenance of the Cable Car line to ensure functionality and life safety.

All the tunnels discussed in this paper are recognised as heritage structures in the Heritage New Zealand List [6] and/or the Wellington City District Plan [7]. The tunnels were originally

Table 1: Heritage tunnels of the Wellington urban transportation network discussed in this paper.

\begin{tabular}{|c|c|c|c|c|c|c|}
\hline Tunnel Name & $\begin{array}{l}\text { Managing } \\
\text { Authority }\end{array}$ & $\begin{array}{c}\text { Year } \\
\text { Opened }\end{array}$ & $\begin{array}{c}\text { Year } \\
\text { strengthened }\end{array}$ & Length (m) & $\begin{array}{l}\text { Height / width } \\
\text { (m) }\end{array}$ & Significance \\
\hline $\begin{array}{l}\text { Hataitai Bus } \\
\text { Tunnel }\end{array}$ & $\begin{array}{l}\text { Wellington City } \\
\text { Council }\end{array}$ & 1907 & 2015 & 310 & $5.25 / 4.0$ & $\begin{array}{c}\text { Wellington City network - bus access } \\
\text { to eastern suburbs }\end{array}$ \\
\hline $\begin{array}{l}\text { Northland } \\
\text { Tunnel }\end{array}$ & $\begin{array}{l}\text { Wellington City } \\
\text { Council }\end{array}$ & 1927 & 2018 & 90 & $5.5 / 7.5$ & $\begin{array}{l}\text { Wellington City network - access to } \\
\text { Northland suburb }\end{array}$ \\
\hline $\begin{array}{l}\text { Seatoun } \\
\text { Tunnel }\end{array}$ & $\begin{array}{l}\text { Wellington City } \\
\text { Council }\end{array}$ & 1907 & 2020 & 144 & $5.4 / 8.1$ & $\begin{array}{c}\text { Wellington City network - access into } \\
\text { the Seatoun suburb }\end{array}$ \\
\hline $\begin{array}{l}\text { Wellington } \\
\text { Cable Car } \\
\text { Tunnels }\end{array}$ & $\begin{array}{l}\text { Wellington Cable } \\
\text { Car Company }\end{array}$ & 1902 & $\begin{array}{c}\text { Yet to be } \\
\text { strengthened }\end{array}$ & $3 \times 90$ & $5.0 / 6.1$ & $\begin{array}{l}\text { Wellington Cable Car line - historical } \\
\text { and iconic feature of Wellington city - } \\
\text { connecting CBD with Victoria } \\
\text { University and Kelburn suburb }\end{array}$ \\
\hline
\end{tabular}


built to extend the Wellington tramway system to the suburbs, which assisted in the residential expansion of the city and facilitated its economic development.

The tunnels have some common characteristics:

- They were constructed at the beginning of the last century, using broadly similar construction methodology.

- The tunnel barrels are lined with brick, and in some cases partly with unreinforced concrete.

- The portals generally consist of unreinforced or in some cases lightly reinforced concrete gravity walls.

\section{SEISMIC ASSESSMENT METHODOLOGY}

The methodology followed for seismic assessment and design of the strengthening of the tunnels presented in this paper generally followed the stages described in the sections below.

\section{Desk Study}

Desk study was an initial and very important part of the assessment. Desk studies included review of available information such as as-built drawings, construction stage photographs, relevant geological and geotechnical information and subsequent inspection and maintenance reports. The review of historical information in particular, including photographs and newspaper articles of the time, sourced from regional and national libraries, provided some useful insights about the construction methods, the quality of the rock mass, and in some cases the failures that occurred during construction. Some historical photographs from the construction of Seatoun tunnel portals are presented in Figure 3 and Hataitai Bus tunnel in Figure 4. The Hataitai photograph shows a tunnel collapse during construction, though its exact location is not known.

\section{Investigations}

Site investigations were carried out to inform the seismic assessments and consequent design of strengthening measures for the tunnels. These are described in the following sections.

\section{Topographical Surveys}

Topographical surveys were carried out at the tunnel portals, including side and wing walls and associated slopes, or at other locations critical for the assessment of the tunnels. In some cases, the topographical surveys, apart from the conventional ground surveys, included laser scan surveys. The laser scan provided 3D models of the portal structures, slopes and tunnel sections, which were used for structural and stability analyses, for design of the mitigation measures and the architectural design of strengthening. Examples of the images obtained from the laser scan are shown in Figure 5.

\section{Structural Investigations}

Inspections of the condition of the tunnel lining and portal and wing walls were carried out by structural, geotechnical and tunnel engineers and material specialists, to visually assess the condition of structural parts of the tunnel barrel and portals.

Core samples of the concrete or brick were obtained at selected locations of the tunnel barrel lining and portal walls to examine the quality of the materials, the thickness of the structural elements and to investigate the presence of reinforcement, when this was not clear from the available drawings. Laboratory compressive strength tests were carried out on these samples.
In the case of brick cores, tests were carried out to assess the compressive strength of the brick and the mortar, see Figure 6.

Coring was extended into the ground behind the lining and portal structures to investigate the presence and thickness of backfill or of voids, and the quality of rock behind the portal walls and lining. CCTV surveys were carried in the cored holes where considered necessary (e.g. in Northland tunnel).

\section{Geological and Geotechnical Investigations}

Engineering geological mapping was carried out on slopes associated with the tunnel portals, and other soil and rock outcrops in the vicinity of the tunnel and portals. The mapping provided understanding of the thickness of the overburden soils, the profile and quality of bedrock, and the presence, orientation and spatial distribution of rock defects.

The engineering geological mapping also assisted in identifying the areas of uncertainty with respect to the ground and groundwater conditions and enabled more efficient scoping of necessary geotechnical investigations.

Geotechnical investigations comprised boreholes, trial pits and machine auger holes, as appropriate. Laboratory uniaxial compressive strength tests were carried out on selected rock samples, to assess the strength of the rock. Downhole geophysical surveys were carried out in the boreholes, comprising downhole Acoustic and Optical Televiewer surveys (ATVs and OTVs) in cases where the presence and orientation of rock defects were critical for the stability of the tunnel, the portals and associated slopes. The results and interpretation of these are discussed in more detail in the Cable Car Tunnels section of this paper.

\section{Engineering Assessment}

\section{Precedent Behaviour of Tunnels in Earthquakes}

An understanding of the precedent behaviour of tunnels in earthquakes is important in assessing the seismic performance of the tunnels. International experience generally shows that underground structures perform better in earthquakes than surface structures [11]. This appears to be mostly the case when the tunnels are at substantial depths below the ground surface and when they are constructed in good geological conditions.

Several studies of tunnel performance during earthquakes have been published [12,13], and of particular use are reviews of the performance in large earthquakes in Taiwan $[14,15]$. When damage to mined sections of tunnels was observed, these were indicated to be situations where:

- the tunnel is close to the epicentre, or close to the ground surface, or in large earthquakes, i.e., damage increases as peak ground acceleration increases;

- the tunnel lining is substandard, due to design not taking adequate consideration of ground, groundwater or seismic loads, or due to time deterioration;

- the tunnels are intersected by active faults that rupture;

- the tunnels are subject to asymmetrical loads in proximity to slopes or are affected by some form of slope instability.

The studies indicate that no or minor damage was observed, where peak ground accelerations were up to $0.2 \mathrm{~g}$, while moderate to severe damage could be expected for peak ground accelerations greater than $0.4 \mathrm{~g}$ to $0.5 \mathrm{~g}$, depending also on other factors, such as those mentioned above. 

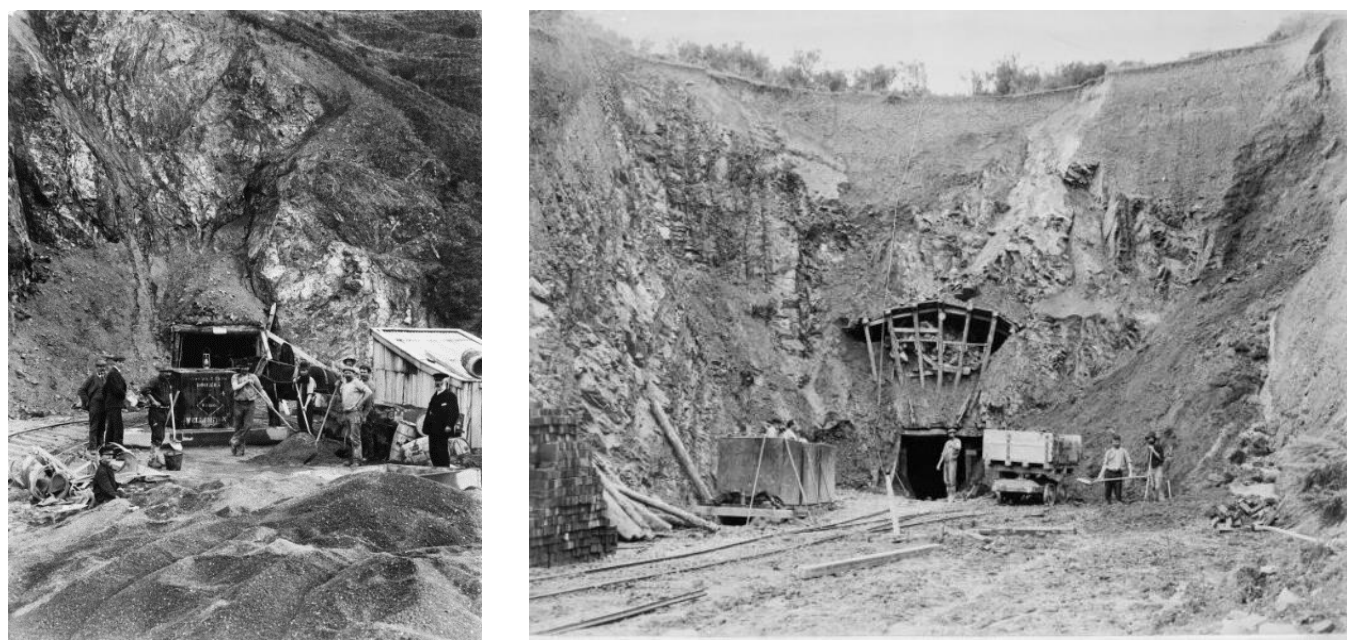

Figure 3: Photographs of the construction of the portals of Seatoun tunnel taken circa 1905 - 1906 [8,9].

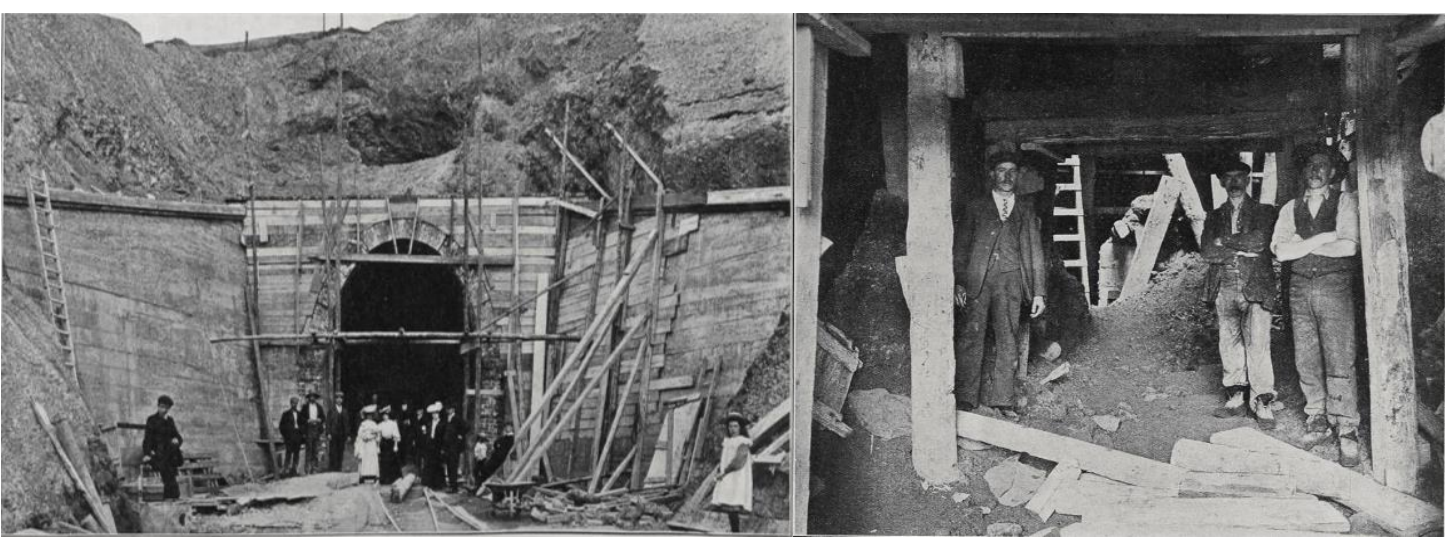

Figure 4: Photographs of the construction of the portals (left) and tunnel section (right) of Hataitai tunnel taken in 1907. The photograph of the tunnel section is following a roof failure [10].
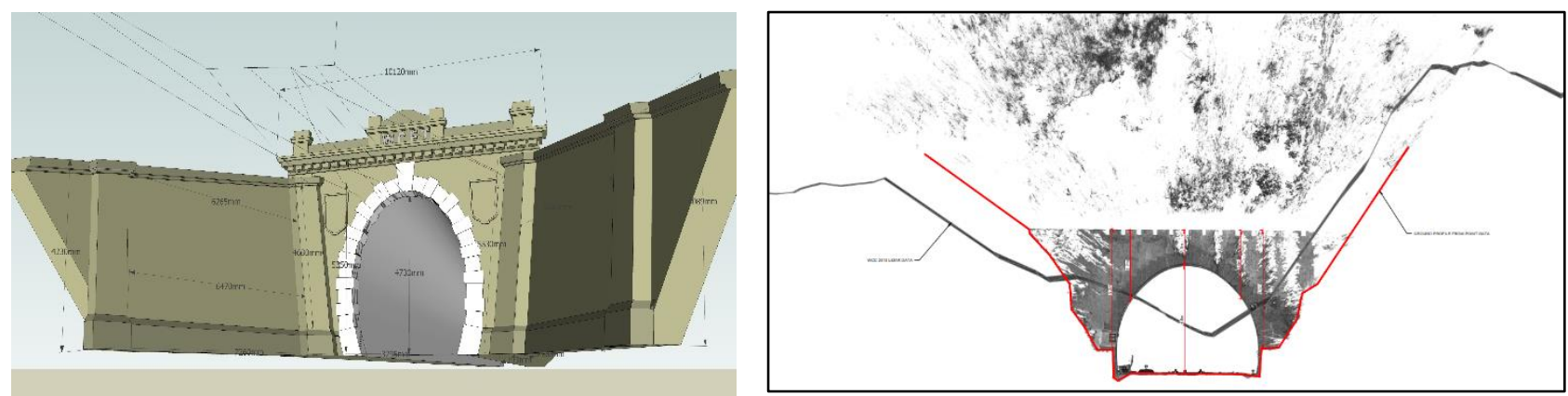

Figure 5: Left: 3D model from the laser scan of the Hataitai tunnel portals, used for architectural design. Right: Cross section at the portal of the upper tunnel of the Cable Car tunnels used for stability and structural analysis. The red line depicts ground topography captured from the laser scan, combined with topography from the Council Lidar data, depicted by the grey line.
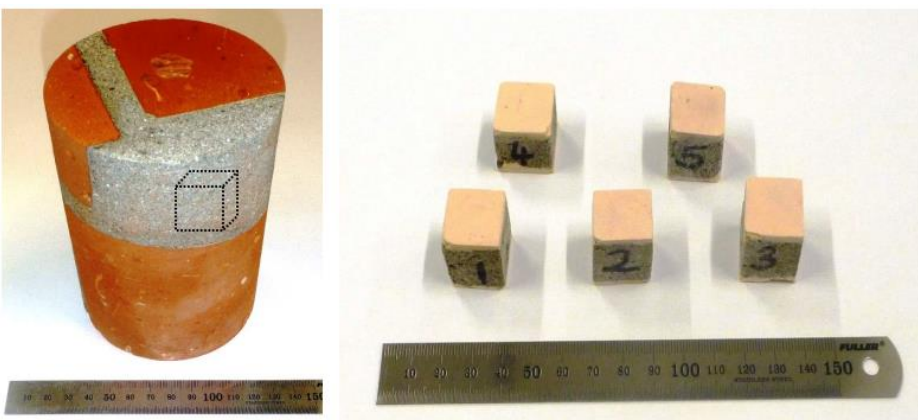

Figure 6: Core sample taken from the brick lining (left); cubes of mortar cut from bedding, shown with capping for testing (right). 
The observations from the international literature were confirmed in the New Zealand context by the damage recorded in the railway tunnels affected by the magnitude M7.8 Kaikoura earthquake of 14 November 2016. The extent of the damage to the mined railway tunnels away from the portals was minor, except when adjacent to slopes, landslides, or fault rupture, and was far less than the damage to adjacent sections of above ground railway where significant slope and embankment failures occurred. The damage in the tunnel lining observed consisted of minor cracking where adverse combinations of defects were present and were readily repaired by techniques such as installation of rock bolt arrays [16]. However, more substantial damage was observed in tunnels near slopes and a tunnel that crossed a rupture section of the Hope Fault. Although there were no recorded motions near the tunnels, the peak ground accelerations in the area are likely to have been of the order of $0.5 \mathrm{~g}$ to $0.7 \mathrm{~g}$.

Observations in New Zealand as well as overseas earthquakes indicate that the tunnel portals experienced more damage than the underground sections.

\section{Ground Motions}

The expected performance of different parts of the Wellington city tunnels under consideration in this paper was assessed in a range of seismic events, with recurrence intervals of 25,100 , 250, 500 and 1000 years, as well as in a magnitude 7.5 earthquake associated with a characteristic rupture of the Wellington Fault. The tunnels are located at distances ranging from $250 \mathrm{~m}$ to $7.5 \mathrm{~km}$ approximately from the Wellington Fault, with the Northland and Cable Car tunnels being the closest and Seatoun tunnel being the furthest away.

Ground motions for the seismic assessment of the tunnels and their portals were based on NZS 1170.5:2004 [17], assuming a site subsoil Class B or C, depending on the ground conditions at the location of each tunnel element assessed.

\section{Assessment of the Seismic Performance of the Tunnel Barrel}

The tunnel barrel can experience three principal types of deformation under seismic shaking: axial, curvature and racking (in rectangular cross-sections), or ovaling (in circular cross-sections) $[11,18]$.

The axial and curvature strains of the ground are not usually critical for horizontally or nearly horizontally aligned linear tunnels [11]. The shear distortion of ground caused by vertically propagating shear waves is probably the most critical and predominant mode of seismic motions for most tunnels. It causes a circular tunnel to oval and a rectangular underground structure to rack and could lead to cracking of the tunnel lining. The magnitude and severity of deformation of the tunnel depends on the elastic parameters of the surrounding ground, the depth of the overburden, the diameter of the tunnel and the relative stiffness of the lining and the ground [11].

More details on the methodology and the results of the tunnel lining assessments will be presented in the case histories discussed in the following sections. The linings of the tunnels discussed in this paper were assessed to perform adequately with minor to moderate damage under large earthquake events, apart from a section of the middle tunnel of the Wellington Cable Car, which is in close proximity to a steep slope, has shallow overburden depth and is affected by slope creep movements. This is discussed in more detail in the Cable car tunnel section.

The effect of failure of a rock wedge (rock block) formed by a combination of unfavourably oriented rock defects, on the tunnel lining was also examined (see Figure 7). Such types of failure occur in Wellington Greywacke and have been observed in tunnels and on slopes around Wellington. A characteristic wedge failure observed on the roof of the unlined Orongorongo water supply tunnel in Wainuiomata, which is formed in Wellington Greywacke is shown in Figure 8.

Such wedge failures are generally expected to be localised along the length of a tunnel but could load the tunnel lining asymmetrically and cause cracking. Due to the highly fractured and variable nature of the greywacke bedrock in the Wellington area, it is generally difficult to assess with certainty, without extensive investigations, the size, shape and location of the wedge failures.

The likely consequences of such failures on the tunnel lining were generally assessed as

- none, to localised minor cracking of the concrete linings;

- localised minor to moderate cracking and dislocation of some bricks for tunnels lined with bricks.

Such damage would be expected in large earthquake events and would be easily repairable.

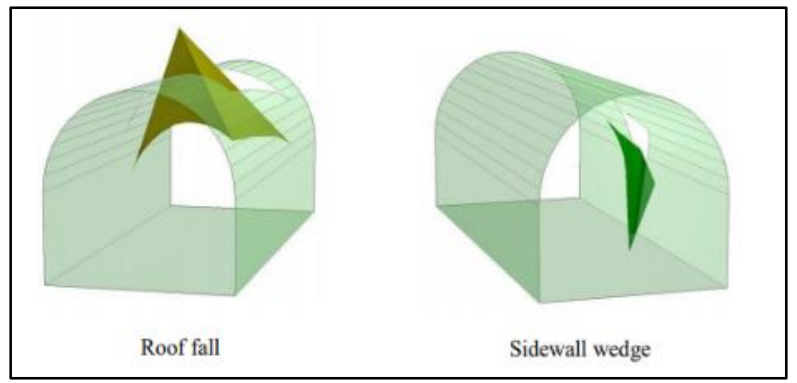

Figure 7: Wedge failure mechanism from tunnel roof and walls [19].

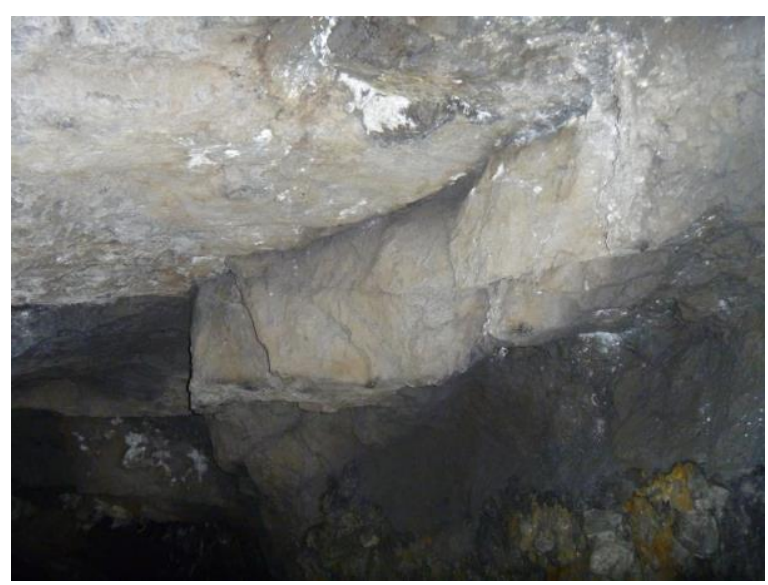

Figure 8: Wedge failure mechanism observed on the roof of Orongorongo water supply tunnel in the Wellington Region.

\section{Assessment of Seismic Behaviour of Portals}

The tunnel portals are more prone to damage under earthquake loading. The portals and side or wing walls of the tunnels discussed in this paper are generally unreinforced retaining walls (or lightly reinforced in the case of Northland tunnel), see Figure 9.

Local stability of the retaining walls was checked for sliding, overturning and bearing type failures for the various heights of the walls, considering the connectivity to the tunnel barrel. A factor of safety against failure was computed as the ratio of resisting forces to the disturbing forces. In addition to the selfinertia loads, earthquake earth pressure forces were considered as acting on a rigid wall [20] as the portal walls and wing walls are usually connected to tunnel barrel and founded on rock. The 
inertia forces were considered with sloping locked-in soil at the retained soil side of the walls.

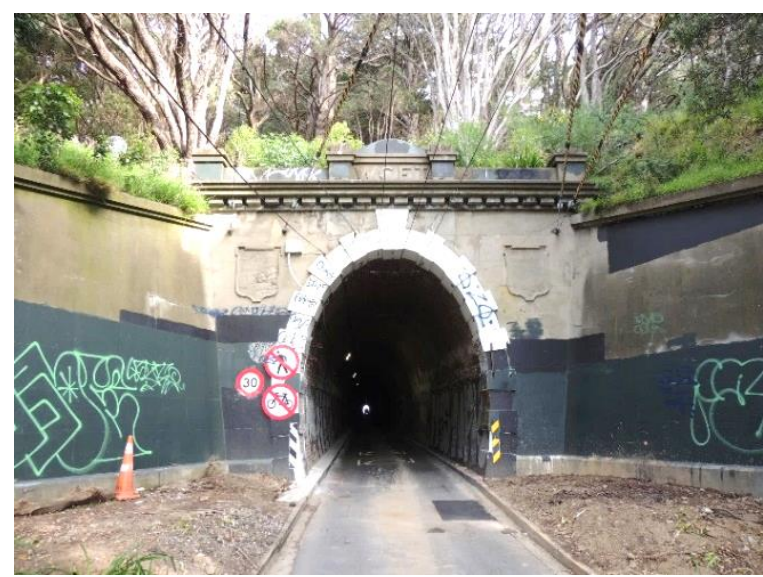

Figure 9: Hataitai Bus tunnel west portal, parapet and wing walls (before the strengthening works).

Other features of the tunnel portals, such as parapet walls above the tunnel portals, were also assessed for their seismic behaviour. These features were usually not structurally connected with the tunnel barrel.

\section{Assessment of Seismic Behaviour of Slopes}

The stability of the slopes associated with the tunnel portals are important for both the performance of the tunnel structure, but also for the overall resilience of the route. It is insufficient to only stabilise the structural components of a tunnel portal to achieve satisfactory performance in a large earthquake if large landslips on the associated slopes could block the road at the tunnel approaches for a few weeks. In some instances, as for example in the Hataitai Bus tunnel, rockfall from the slopes above the portals also pose traffic safety issues, see Figure 10.

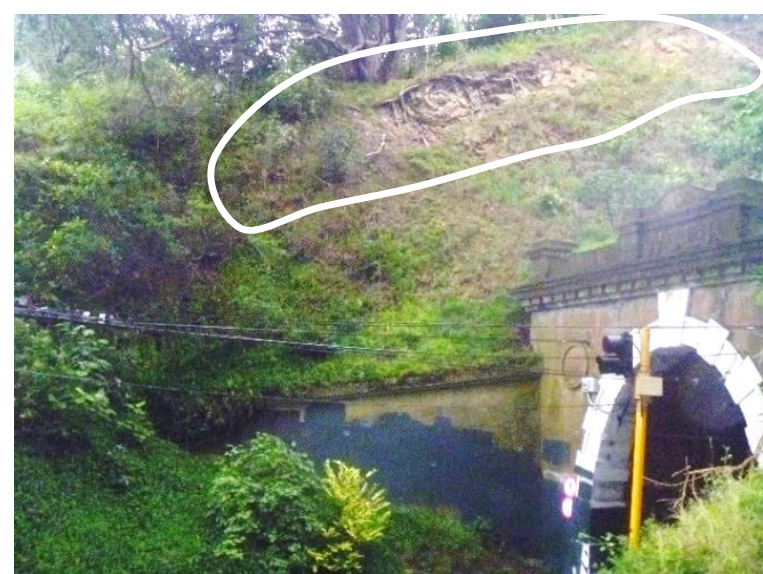

Figure 10: Rockfall hazard from slope above the east portal of the Hataitai Bus tunnel (rockfall source shown in white).

Therefore, critical slopes associated with the tunnel portals were also assessed, and where necessary, hazards were mitigated as part of the resilience enhancement of the tunnels. These were generally rock slopes and were assessed considering the rock quality and the orientation and persistence of defects present.

\section{DESIGN OF STRENGTHENING MEASURES}

\section{Design Philosophy}

The design of strengthening measures for the portal walls and wing walls followed a performance-based design approach.
This approach ensures acceptable performance of the walls, by limiting displacements of the walls to acceptable levels in the different earthquake events, to ensure that the structure does not collapse, and the road will remain open albeit with some minor damage of the portal walls. For slopes, small slips that can be readily cleared were accepted, provided large failures that would not affect the tunnel structure or close access for long periods are prevented. This approach was adopted by Brabhaharan and Saul [21] from the early stages of the Wellington City Council strategy of assessing and enhancing the resilience of their road network.

The performance-based design approach adopted has enabled the development of cost-effective solutions to enhance the earthquake performance and enabled such strengthening works to proceed. The performance-based approach to geotechnical design was incorporated into the Waka Kotahi - New Zealand Transport Agency Bridge Manual [22] for design of highway structures in New Zealand [23]. This has now become a common established approach for the design of retaining walls, embankments and slopes in New Zealand.

The strengthening measures of the tunnels were designed for a design life of 100 years. An Importance Level of 2 was adopted in accordance with the Bridge Manual [22].

\section{General Strengthening Concepts}

Methods of strengthening generally adopted for the tunnels comprised:

- Ground beams: these were placed above the tunnel arch and immediately behind each of the tunnel portal walls and parapets and tied to provide support to the portal structure above the tunnels.

- Reinforced concrete buttresses: these were used to strengthen the portal or wing walls. The buttresses were socketed into rock at their bases, using either shallow foundations or piles, depending on the ground conditions.

- Ground anchors, through the portal and wing walls and the reinforced concrete elements to tie the structures into rock.

The ground anchors were double corrosion protected by pregrouting into high density polyethylene (HDPE) sheaths to provide a 100-year design life, and their heads were carefully concealed into the walls and buttresses.

New reinforced concrete beams and buttresses, together with the ground anchors, are the principal load resisting elements of the strengthened tunnel portals. These are arranged so that the load demand on the original, mostly unreinforced or lightly reinforced but robust walls is significantly reduced, and these can span between the new elements.

A key feature initially developed for soil nails by Brabhaharan [24] and adopted for the ground anchors was the adoption of post-grouting. During post-grouting, the anchors were pressure grouted using a tube-a-manchette through nodes in a post-grout tube grouted-in during the primary grouting. This minimised the need for preliminary grouting and re-drilling and enhanced the bond capacity of the anchors in the variable rock conditions encountered near the tunnels. It also minimised construction time and cost.

\section{Heritage and Architectural Design}

The strengthening works were architecturally designed to preserve the existing features, minimise the effects on the appearance of the structures and be in line with their heritage status. More specifically:

- The ground beams were installed and hidden behind the parapets of both portal walls, to have no impact on the aesthetics of the tunnel. 
- The new concrete elements, such as the buttresses, were positioned and detailed to provide an appearance consistent with the existing features and finish.

- The heads of the rock anchors were concealed and finished flush with the existing surfaces.

- Plastering was carried out to provide a consistent finish and painting of all the portals on completion of the works, using colours close to the original concrete to maintain the character of the tunnel.

\section{Business Case for Strengthening}

Strengthening concepts and design were developed by the authors, who also managed the implementation of the strengthening works. Business cases were prepared to document the resilience benefits including economic analyses and the assessing the benefit-cost of carrying out the strengthening works to facilitate funding subsidy for the work from central government. The cost of strengthening each of the tunnels was of the order of \$1 Million to \$2 Million (New Zealand dollars), and the strengthening had benefit-cost ratios of the order of 4 to 8 .

\section{HATAITAI BUS TUNNEL}

\section{Description}

The Hataitai Bus tunnel connects the City Centre and the suburb of Mt Victoria (west portal) to Hataitai (east portal) and the eastern suburbs. The tunnel was initially designed for the electric tramcars only. It is single lane, nowadays used by buses only, with traffic lights at either side controlling the buses coming from each direction. The tunnel is $310 \mathrm{~m}$ long with an arch about $5.25 \mathrm{~m}$ high and $4 \mathrm{~m}$ wide and is lined with a $450 \mathrm{~mm}$ thick brick lining. The portals at each end comprise mass concrete portal walls and wing walls. The eastern portal is constructed on rock while the western portal is located on fill.

\section{Seismic Performance Assessment}

A previous seismic assessment of the Hataitai bus tunnel concluded that the tunnel barrel and lining will perform adequately in the range of earthquakes discussed in the previous sections, provided that the portals provide confinement to the tunnel lining. The stability analysis of the portals and wing walls showed that they are marginally stable for the 25-year serviceability limit state (SLS) seismic event. Displacements greater than $100 \mathrm{~mm}$ could be expected for earthquake events larger than the SLS event, and failure by sliding and/or overturning could be expected for the ultimate limit state (ULS) event, with a recurrence interval of 1000 years

The strengthening works included ground beams behind the portal walls to strengthen the slope behind the portal walls and retain the parapet walls, and reinforced concrete buttresses in front of the portal and wing walls that were tied back with $6 \mathrm{~m}$ to $14 \mathrm{~m}$ long rock anchors (see Figure 12). More details about the Hataitai Bus tunnel strengthening works were provided by Arumugam and Brabhaharan [25].

Rockfall hazard was identified on the slopes above the eastern portal, causing a maintenance issue and safety risk for the road and tunnel users. The source of the rockfall above the portal is shown in Figure 10. Rockfall was generated by unfavourably oriented rock defects, forming rock blocks that became loose with time and failed under static conditions, exacerbated by rainfall events. The risk to road users under small, frequent events was assessed as minor and consisted more of a nuisance and maintenance issue. The risk under severe storm and earthquake events was, however, assessed as high. Rock fall protection measures were implemented, comprising a high strength steel wire mesh (nominally $1770 \mathrm{~N} / \mathrm{mm}^{2}$ ), single twisted into rhomboidal mesh, fixed on the slope with a $3.0 \mathrm{x}$ 3.0 metre pattern of 4-metre-long rock bolts, see Figure 11.

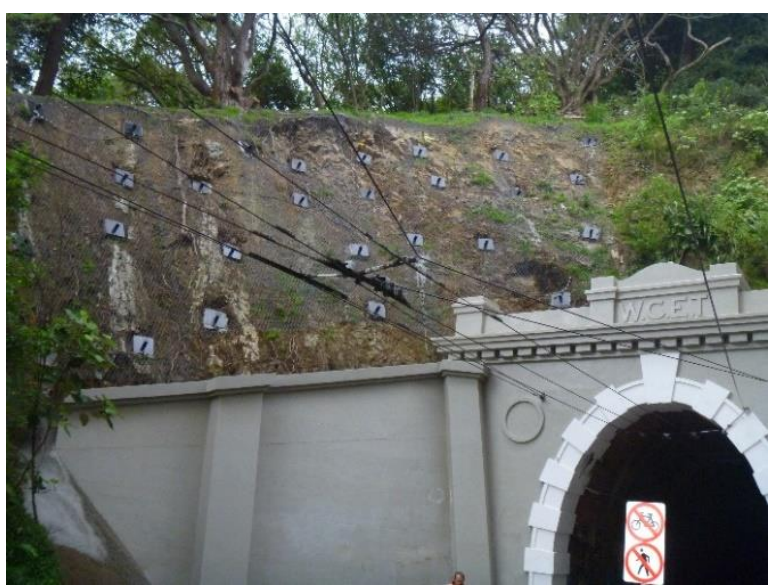

Figure 11: Rockfall protection mesh installed above the Hataitai end portal. View of the finished portal walls.

\section{NORTHLAND TUNNEL}

\section{Description}

The Northland tunnel was built circa 1927 to provide a tramcar link to the suburb of Northland (see Figure 13). It is $90 \mathrm{~m}$ long, $7.5 \mathrm{~m}$ wide and $5.5 \mathrm{~m}$ high. It now provides vehicle and pedestrian access along Northland Tunnel Road and connects Northland to the suburb of Karori.

The tunnel lining comprises an approximately $2.5 \mathrm{~m}$ high reinforced concrete wall with a reinforced concrete arch on top. There is a $1 \mathrm{~m}$ wide footpath on either side with a steel handrail installed on the western side. The tunnel is overlain by sandstone rock of Wellington greywacke formation at the northern end and at the southern end is overlain by a thin layer of sandstone, overlain by fill. A view of the north portal of the tunnel before the strengthening works is shown in Figure 14.

In 1925, following the construction, an inspection was conducted by the Public Works Department. The inspection concluded that the tunnel was unsafe due to the following issues:

- Numerous cracks were observed throughout the tunnel, some of which had opened up to $25 \mathrm{~mm}$.

- The lining did not have a uniform thickness throughout the tunnel. The lining was split into $4.3 \mathrm{~m}$ lengths but with no reinforcement was installed to connect the sections together.

- Bars left behind the concrete in the tunnel walls would decay over time and cause the ground to settle.

- The vibration caused by the trams going through the tunnel could affect the broken concrete, resulting in a risk of failure of the side walls. 

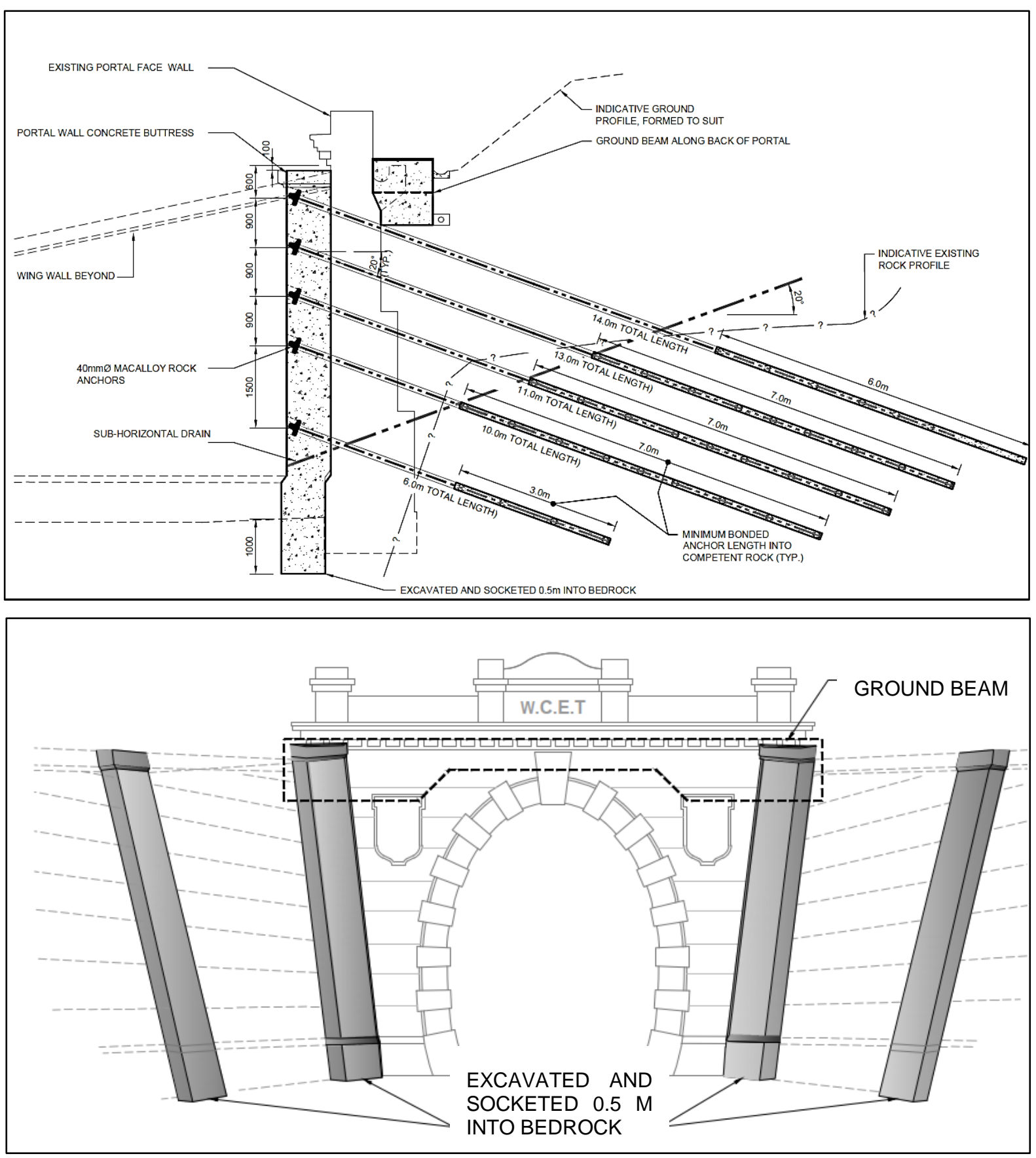

Figure 12: Typical section of strengthening measures through the portal walls-Hataitai bus tunnel.

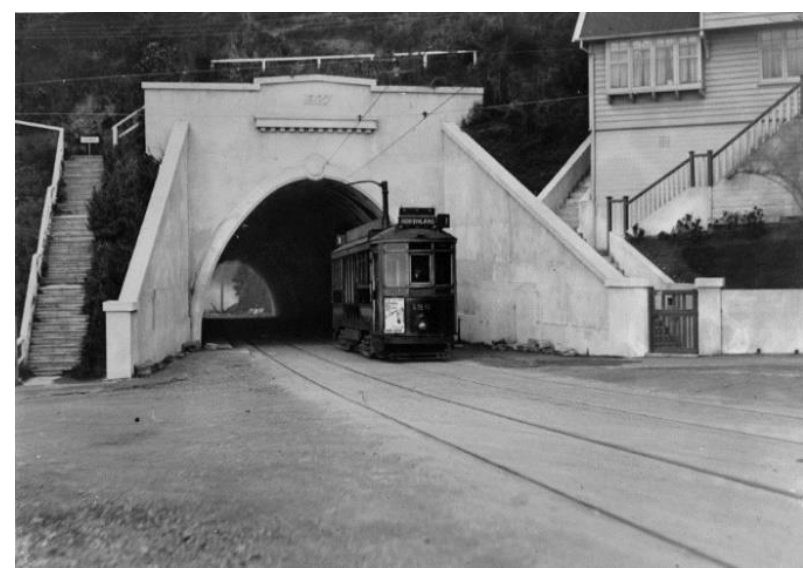

Figure 13: Tram passing through the northern portal of the Northland tunnel on inauguration day, 1929 [26].

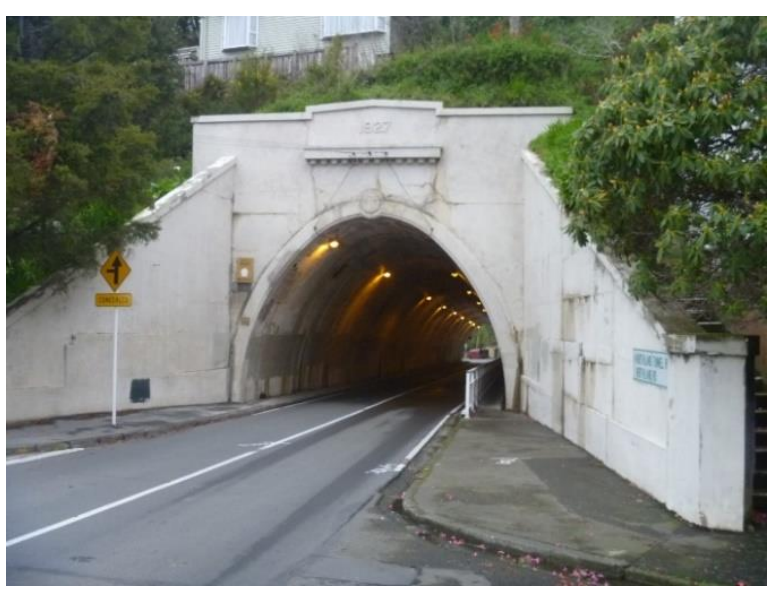

Figure 14: North portal of Northland tunnel (photograph taken before the strengthening works). 


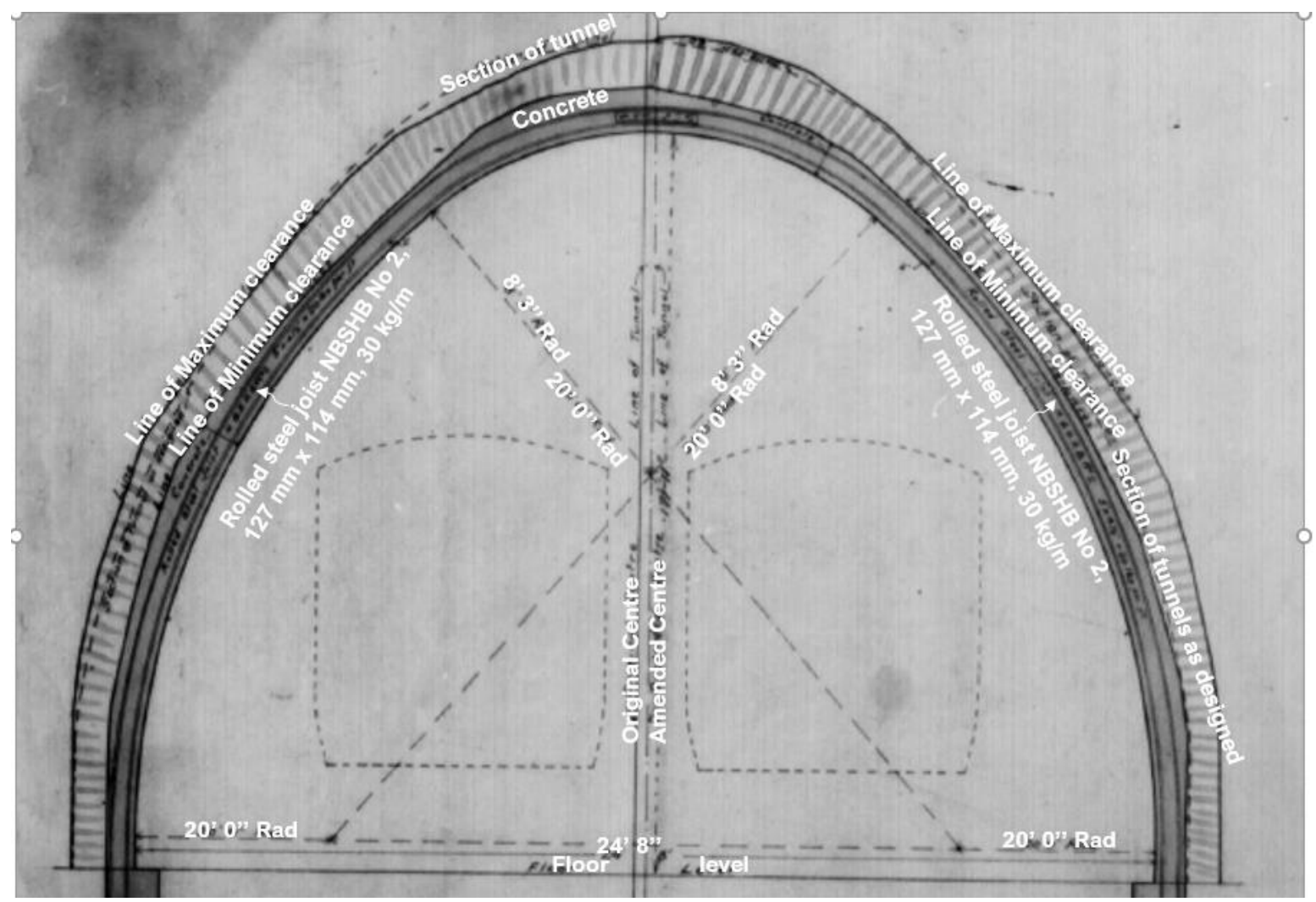

Figure 15: Strengthening of the Northland tunnel immediately after completion of initial construction.

As a result of these issues, the tunnel lining was strengthened immediately after construction, using steel sets and an overlay of reinforced concrete. The strengthening is understood to have comprised overlaying the original lining with steel sets (rolled steel joists new British Standard heavy beam referenced as NBSHB No 2, $127 \mathrm{~mm}$ x $114 \mathrm{~mm}, 30 \mathrm{~kg} / \mathrm{m}$, Figure 15, [27]) and reinforced concrete of $450 \mathrm{~mm}$ thickness. The steel sets were located at $1 \mathrm{~m}$ centres over the northern $45 \mathrm{~m}$ length of the tunnel, and at $0.75 \mathrm{~m}$ centres over the remaining southern section.

\section{Seismic Performance Assessment of Tunnel Barrel}

Coring investigations through the lining confirmed the increased thickness of lining. The concrete coring also identified voids, which in some cases were up to $0.6 \mathrm{~m}$ wide and cracking in the lining. Voids between the lining and the surrounding ground were not common, as the lining was either in direct contact with the rock or the void was infilled.

Laboratory testing was carried out on the core samples to determine the strength of the lining. The testing confirmed that the concrete lining along the southern end of the tunnel, constructed in fill, had higher strength $(61-77 \mathrm{MPa})$ than the concrete in the northern end (33 - $46 \mathrm{MPa}$ ) constructed in rock. It appears that the variability in the ground conditions was considered when the tunnel was strengthened.

The seismic performance of the tunnel barrel was assessed for the range of earthquake events discussed in the previous sections. The cracking and voids in the lining were considered in the assessment by reducing the effective thickness of the lining. Due to the variation of the soil profile over the length of tunnel barrel, two different soil profiles overlying the tunnel barrel were examined: one in sandstone and one in fill. More details on the results of the assessment were presented by Arumugam and Brabhaharan [25].

The assessment of the seismic performance of the tunnel barrel indicated that it would perform adequately in the seismic events considered, despite the variable ground conditions and the increased loading associated with the fill materials at the south section.

It was concluded that strengthening measures were not necessary for the tunnel barrel. There may be some cracking of the lining, particularly at the interface between the soil and rock overburden and along the southern section, but such damage in large earthquakes is expected to be easily repairable. Severe damage or collapse of the tunnel was assessed as unlikely.

\section{Seismic Performance Assessment of Tunnel Portals}

The assessment of the seismic behaviour of the portals concluded that the portal walls and wing walls were marginally stable for the 25-year serviceability limit state (SLS) event and the 100-year event. The walls could be prone to overturning for the 250-year event but based on the assessed displacements the damage expected would be easily repairable. Large and unacceptable displacements or failure in sliding and /or overturning of the portal walls could be expected in the 500year event and the ultimate limit state level (ULS) earthquake event or larger (i.e., 1000-year or larger).

The northern portal parapet wall was also found to have unacceptable behaviour in events larger than the 25-year to 100year ones. Extensive cracking and tilting of the portal walls and parapet could cause a safety hazard for the tunnel users in large events, while severe damage or collapse of the walls could cause closure of the tunnels. Similar conclusions were made for the wing walls of both tunnel portals.

\section{Seismic Performance Assessment of Slopes}

The slope above the northern portal consisting of fill was found to be marginally stable in static conditions. More than a metre lateral displacement could be expected in earthquake events with recurrence periods larger than 100 years. Failure of this slope could block access to the tunnel but could be cleared quickly. 
The southern portal of the Northland tunnel is constructed in a cut slope, which at the west (left) side of the portal is up to $15 \mathrm{~m}$ high (Figure 16). The slope is excavated in rock, at a steep angle of 70 to 75 degrees. This slope has generally performed satisfactorily since the construction of the tunnel, without major instability or rockfall issues reported, but due to its height and steepness and the proximity to the tunnel portals, its stability was included in the assessment.

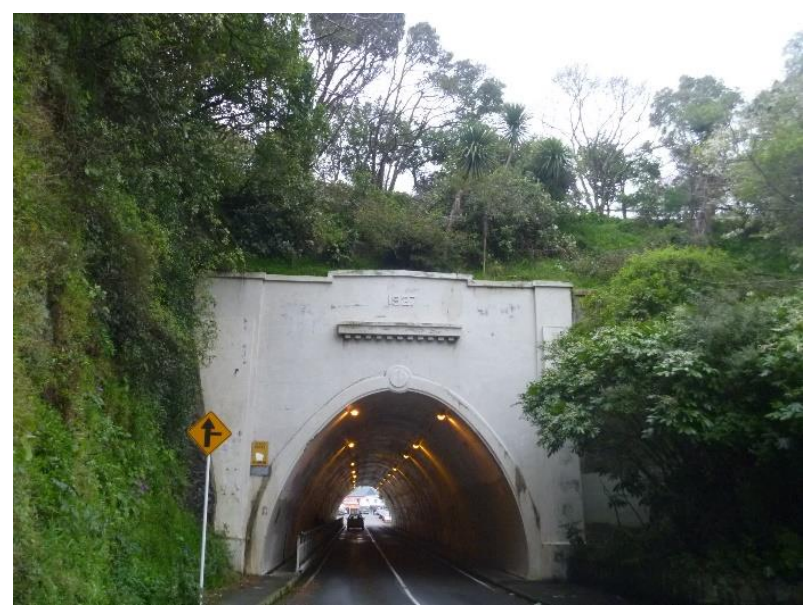

Figure 16: View of the south portal of Northland tunnel. $10 \mathrm{~m}$ to $15 \mathrm{~m}$ high and steep rock slope at the left-hand side of the portal (photograph before the strengthening works).

The assessment concluded that there were unfavourably oriented defects present on the slope that could cause planar / wedge type of failures and rockfall hazard to the users of the tunnel. These failures would not affect the tunnel. Failures of sufficient size, enough to block part of or one lane of road were more likely under a 500-year seismic event. It was considered that these failures could not cause damage to the tunnel, while partial blocking of the road could be quickly cleared after a seismic event. As a result, such failures are acceptable from a resilience perspective. No stabilisation measures were considered necessary based on the condition of the slope at the time of the assessment.

\section{Strengthening Measures}

The results of the assessment indicated the need for strengthening of the portal, parapet and wing walls of the Northland tunnel.

Strengthening concepts were developed and options were compared to select the most suitable methods. The heritage value of the tunnel portals was a key consideration. An option of covering the full face of the tunnel portal and wing walls was considered to address the extensive cracking, but it was not preferred due to the impact on the heritage features. The selected concept included discrete strengthening elements added to the existing structure, with minimal visual impacts. These options were preferred by the Council Heritage Advisor.

A resilience-based design approach was adopted for the seismic strengthening of the tunnel portals, considering functionality and time for recovery as proposed by Brabhaharan [28]. This enabled cost-effective strengthening of the tunnel portals that provided good seismic resilience.

The strengthening adopted for the north portal comprised:

- Reinforced concrete ground beam hidden behind the portal. The beam was connected to the wing walls with drilled and epoxy bonded tie bars.
- Reinforced concrete wall buttresses $(0.5 \mathrm{~m}$ thick by $5.5 \mathrm{~m}$ wide), founded on $600 \mathrm{~mm}$ diameter piles socketed $3 \mathrm{~m}$ into bedrock (typically 3 No piles of $600 \mathrm{~mm}$ diameter).

- Rock anchors typically $8 \mathrm{~m}$ long, $32 \mathrm{~mm}$ dia. $1030 \mathrm{MPa}$, double corrosion protected bars grouted into rock, to tie back the portal and wing wall faces.

Photographs of the north portal after strengthening are given in Figure 17, and the strengthening works are illustrated in the diagrams of Figure 18.

The strengthening adopted for the south portal included (Figure 19):

- A ground beam for strengthening of the parapet wall, which was extended to support the wing wall, and was hidden behind the portal.

- Reinforced concrete overlays to strengthen the existing buttresses on either side of the tunnel entrance, which was tied back with rock anchors.

- Three reinforced concrete columns to strengthen the wing wall, tied back with rock anchors.

- Additional anchors on the portal and wing wall faces. The rock anchors were typically $8 \mathrm{~m}$ long, $32 \mathrm{~mm}$ dia. $1030 \mathrm{MPa}$, double corrosion protected bars grouted into rock, and their heads were installed in pockets in concrete members and concealed with mortar and plastering.

A photograph of the strengthened south portal is shown on Figure 20. The photographs on Figure 17 and Figure 20 illustrate how the strengthening to enhance resilience has been achieved without compromising the heritage values of the tunnel portals.

\section{SEATOUN TUNNEL}

\section{Description}

The Seatoun tunnel (also known previously as Crawford's Tunnel) is a $147 \mathrm{~m}$ long, vehicle and pedestrian tunnel located between Broadway Road in Strathmore and Ferry Street in Seatoun, Wellington. The tunnel was constructed in 1906-1907, originally to extend the tramline to the suburb of Seatoun.

The tunnel provides vital vehicle access through the hill that separates the suburbs of Strathmore and Seatoun. It carries about 6,500 vehicles a day. The alternate access routes over the hills and along the bays are much longer and more vulnerable to slope failure and underslips, hence are less resilient and not expected to be available immediately after a major earthquake.

The tunnel lining comprises cast in-situ unreinforced concrete side walls, about $2.5 \mathrm{~m}$ in height, supporting the brick arch. The tunnel is $8.1 \mathrm{~m}$ wide at road level and has a $6.2 \mathrm{~m}$ wide carriageway, and a $1.2 \mathrm{~m}$ wide footpath raised about $0.6 \mathrm{~m}$ above the carriageway level.

\section{Earthquake Performance Assessment}

A previous assessment of the seismic behaviour of the Seatoun tunnel concluded that strengthening of the tunnel barrel was not necessary. The unreinforced concrete portal and wing walls at both portal ends and the retaining wall on the Strathmore end of the tunnel were found to be vulnerable to failure in moderate to large earthquake events, i.e., with recurrence periods larger than 100 years. Failure of these portal structures could lead to collapse of the tunnel barrel adjacent to the portals. This could cause access into Seatoun to be closed for several weeks or longer, as post-earthquake resources are likely to be focussed on the recovery of the city centre and regional access routes. Strengthening of the tunnel portals was recommended to enhance the resilience of this route. 

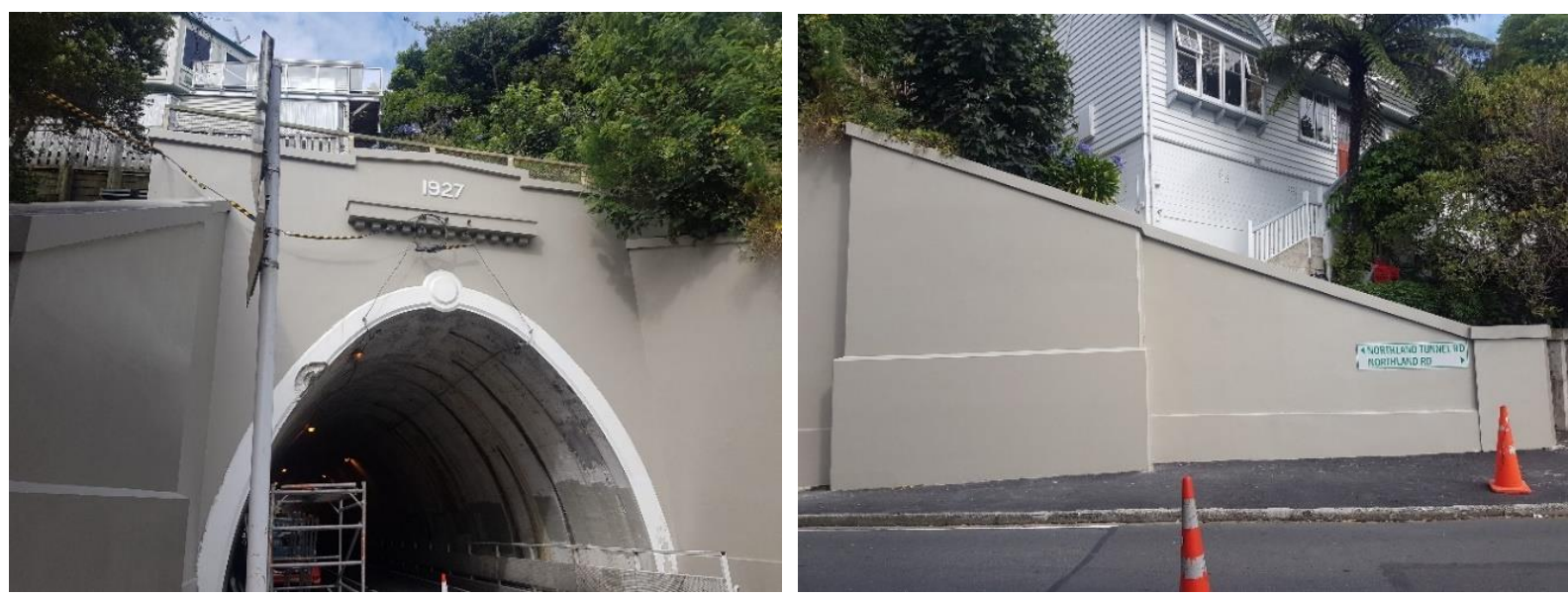

Figure 17: North portal and wing walls after strengthening - Northland tunnel.

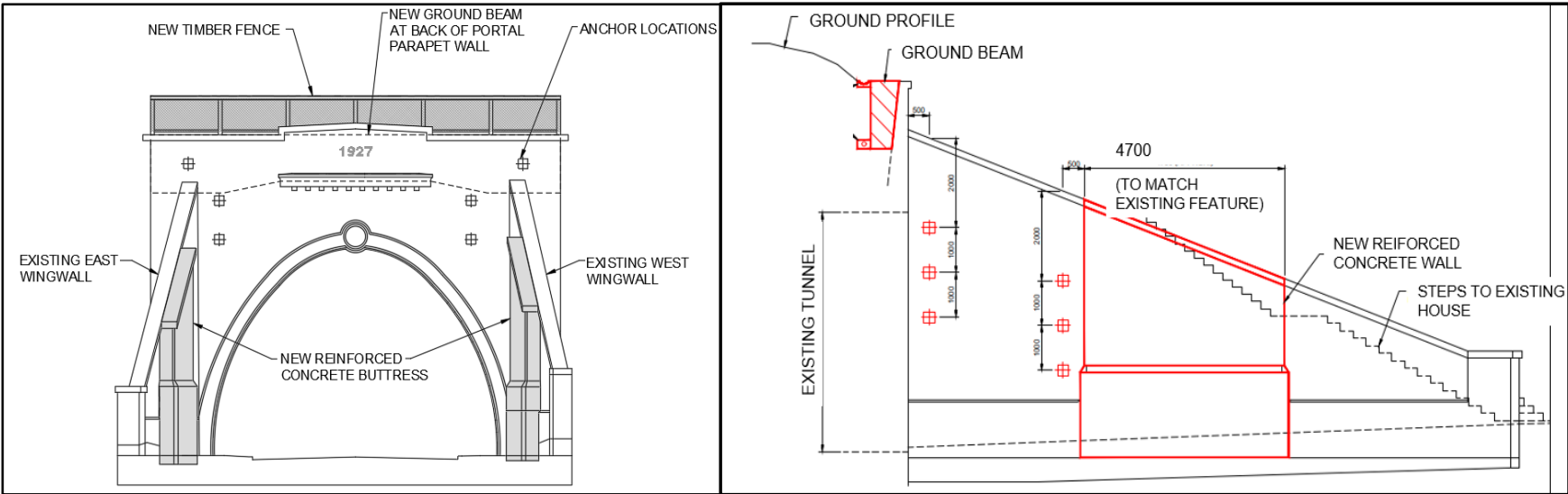

Figure 18: General layout of strengthening measures of portal and wing walls at the north portal of the Northland tunnel.

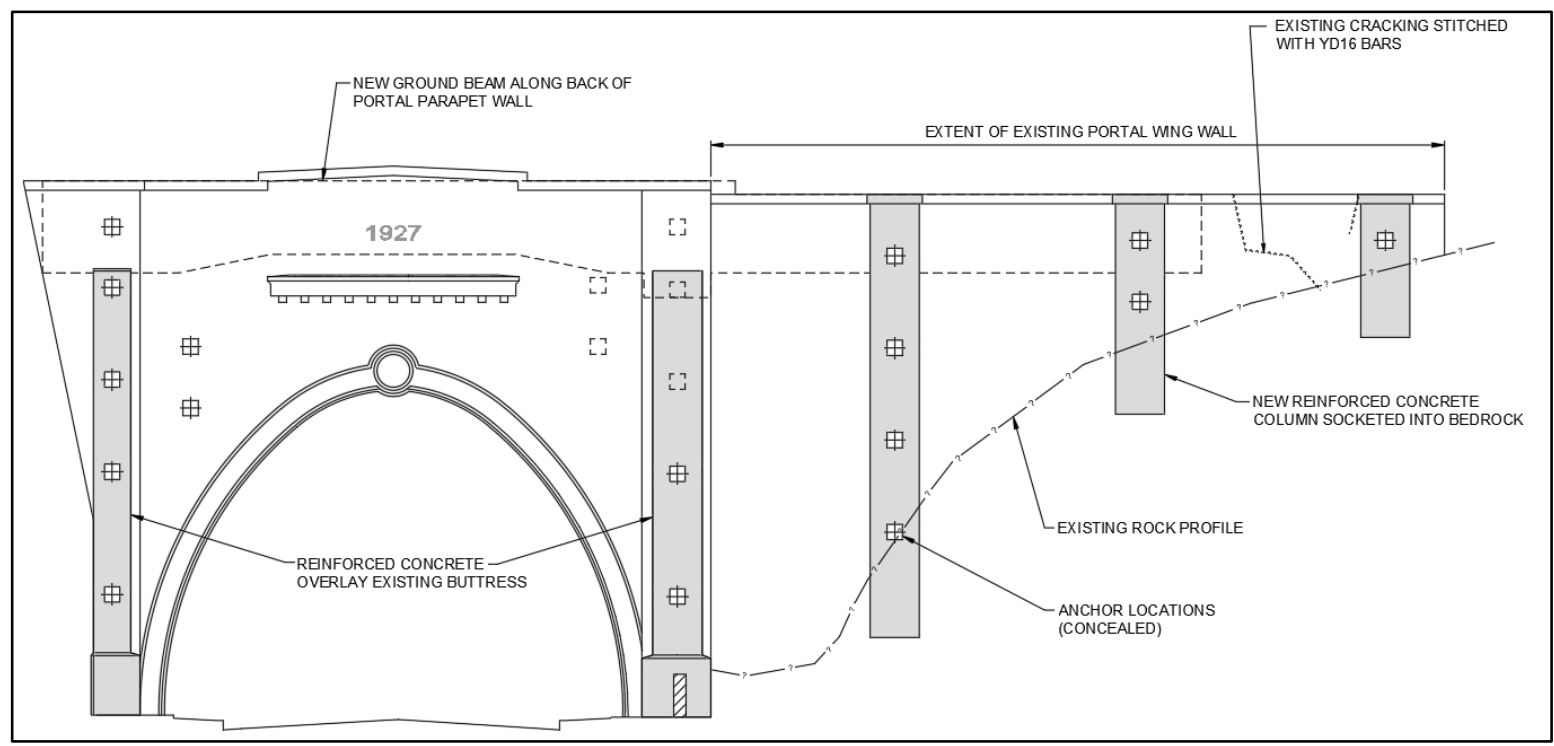

Figure 19: General layout of strengthening measures of portal and wing walls at the south portal of Northland tunnel. 


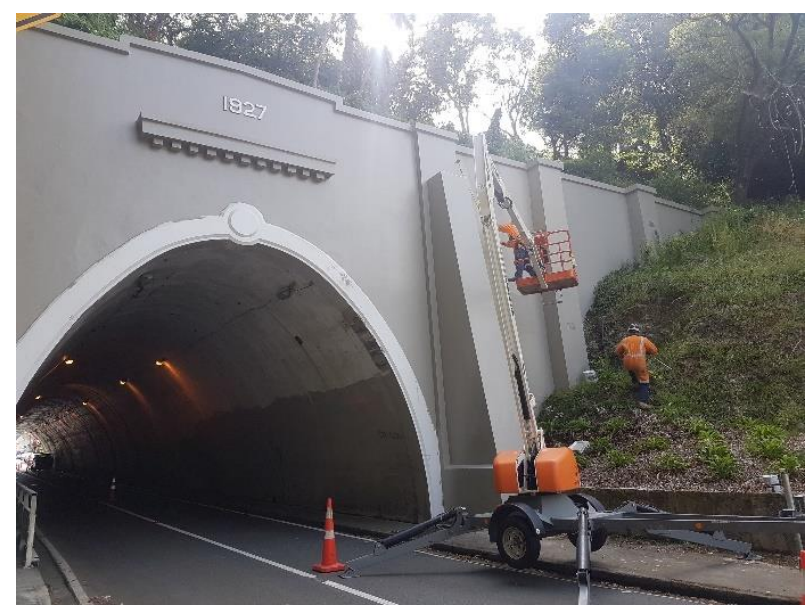

Figure 20: South portal and wing walls post construction of the strengthening measures - Northland tunnel.

\section{Strengthening Measures}

The strengthening works comprised (see Figure 21):

- Reinforced concrete ground beams hidden behind the portal wall to provide lateral support and resist the ground loads from the slope behind.

- Reinforced concrete overlays to strengthen the existing buttresses either side of the portal arch, on both portals.

- Reinforced concrete beam to support the retaining wall on the eastern side of the south portal.
- Rock anchors to tie back the ground beam, buttress overlays and the retaining wall into stable rock.

The rock anchors were typically $8 \mathrm{~m}$ long, $32 \mathrm{~mm}$ dia. $1030 \mathrm{MPa}$, double corrosion protected bars grouted into rock. The anchors were post-grouted using a tube-a-manchette system to provide good capacity and minimise the need for pregrouting and re-drilling in the variable rock conditions. General views of the Strathmore portal before and after strengthening are shown in Figure 22.

\section{WELLINGTON CABLE CAR TUNNELS}

\section{Background}

The Wellington Cable Car runs from Upland Road in Kelburn to Lambton Quay, in the Wellington Central Business District. The total length of the route is $600 \mathrm{~m}$, and it is inclined at a grade of 1:5.06.

The Cable Car line was constructed between 1898 and 1901. The Upland Estate Company, which opened the former farmland at Kelburn for settlement, chose the Cable Car as the principal means of access from the city [29]. The viaducts were replaced with the present steel and concrete structures in 1929. 30 and the cars and motive system were completely replaced in 1978. The operation passed to municipal ownership in 1948 and is now managed by Wellington Cable Car Limited, a subsidiary of Wellington City Council.

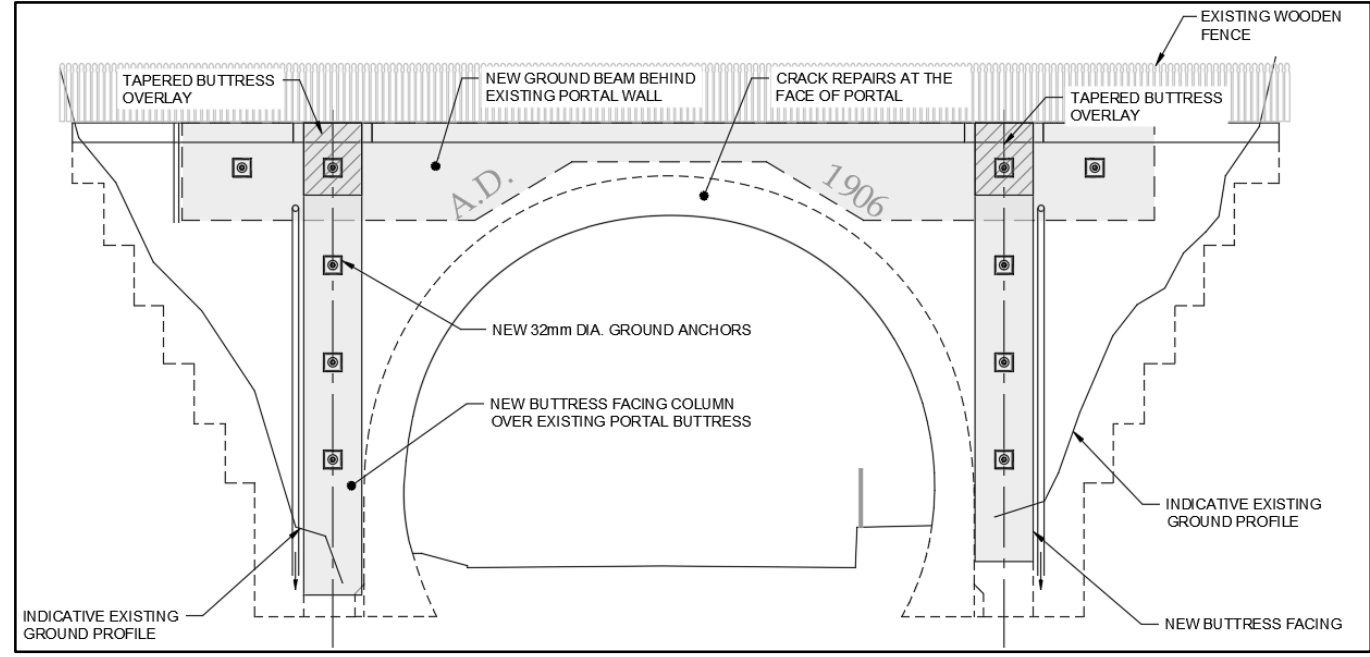

Figure 21: General layout of strengthening measures of Seatoun tunnel portals.
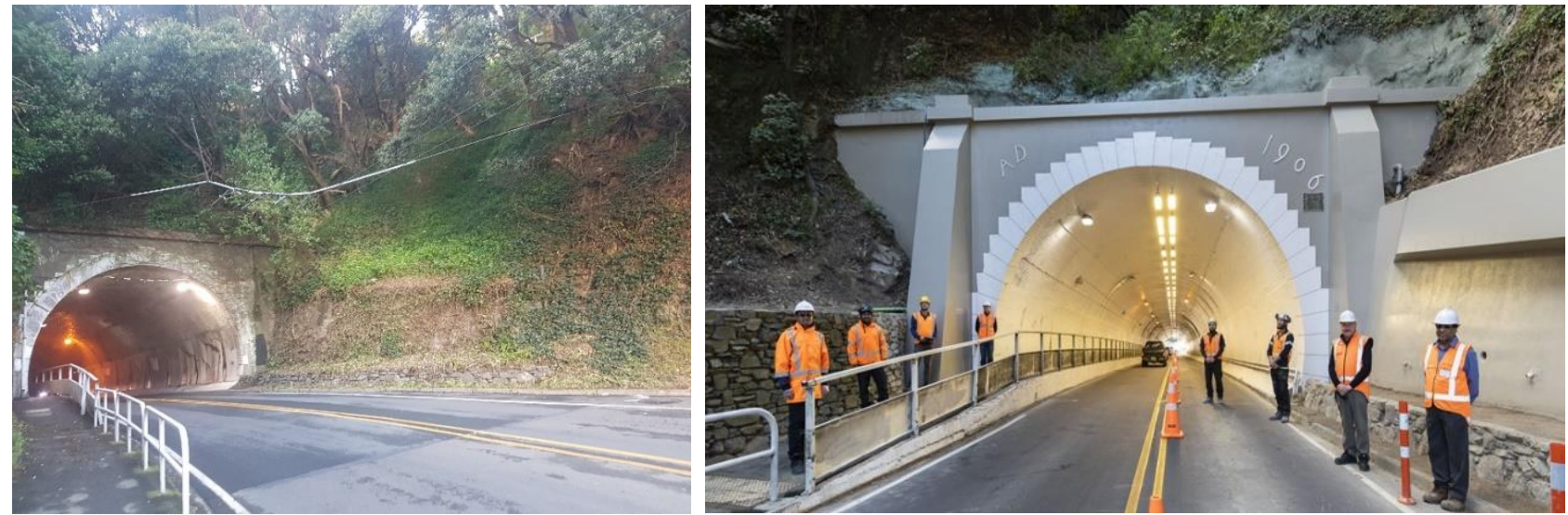

Figure 22: Seatoun tunnel - view of the Strathmore portal, before and after the strengthening works. 
Table 2: The three tunnels of the Cable Car line.

\begin{tabular}{ccccc}
\hline $\begin{array}{c}\text { Tunnel } \\
\text { Name }\end{array}$ & From - to & Length $(\mathbf{m})$ & Portal Designation & $\begin{array}{c}\text { Approximate thickness of } \\
\text { overburden }(\mathbf{m})\end{array}$ \\
\hline $\begin{array}{c}\text { Upper } \\
\text { Tunnel }\end{array}$ & $\begin{array}{c}\text { East of Salamanca road to } \\
\text { Talavera Station }\end{array}$ & $\sim 90 \mathrm{~m}$ & $\begin{array}{c}\text { Upper tunnel - Upper Portal UU } \\
\text { Upper tunnel - Lower Portal UL }\end{array}$ & $10-15$ \\
$\begin{array}{c}\text { Middle } \\
\text { Tunnel }\end{array}$ & $\begin{array}{c}\text { Talavera Station to Clifton } \\
\text { Station - }\end{array}$ & $\sim 103 \mathrm{~m}$ & $\begin{array}{c}\text { Middle tunnel - Upper Portal MU } \\
\text { Middle Tunnel - Lower Portal ML }\end{array}$ & $8-14$ \\
$\begin{array}{l}\text { Lower } \\
\text { Tunnel }\end{array}$ & $\begin{array}{c}\text { East of SH1 to Lambton } \\
\text { Quay Station }\end{array}$ & $\sim 90 \mathrm{~m}$ & $\begin{array}{l}\text { Lower tunnel - Upper Portal LU } \\
\text { Lower tunnel - Lower Portal LL }\end{array}$ & Inferred $15-20$ \\
\hline
\end{tabular}

The Cable Car route is notable for its steep alignment and the remaining older infrastructure, including the formation, tunnels and viaducts (Figure 23). Virtually all the other parts above the formation, including the winding mechanism, are modern.

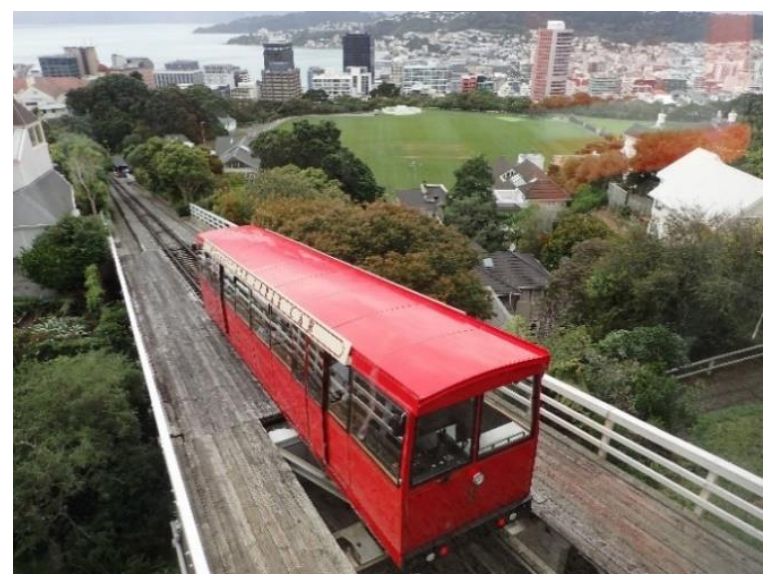

Figure 23: The Cable Car crossing a viaduct. View from Kelburn station.

The route has three tunnels which are approximately $90 \mathrm{~m}$ to $100 \mathrm{~m}$ long. The tunnels are horseshoe shaped with a maximum width of $6.1 \mathrm{~m}$ and a height of about $5 \mathrm{~m}$ (Figure 24). The lining is an arch comprising brick and mortar masonry above the spring line and unreinforced mass concrete walls about $2.2 \mathrm{~m}$ high below the spring line. The tunnels were constructed by excavation and blasting.

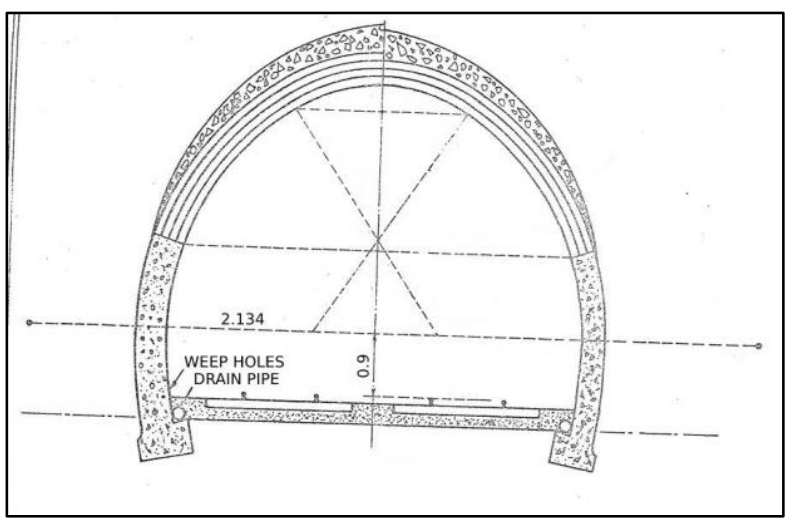

Figure 24: Typical cross section of the Cable Car tunnels.

The characteristics of the tunnels are shown in Table 2. A plan of the Cable Car line and location of the three tunnels is included in Figure 25.

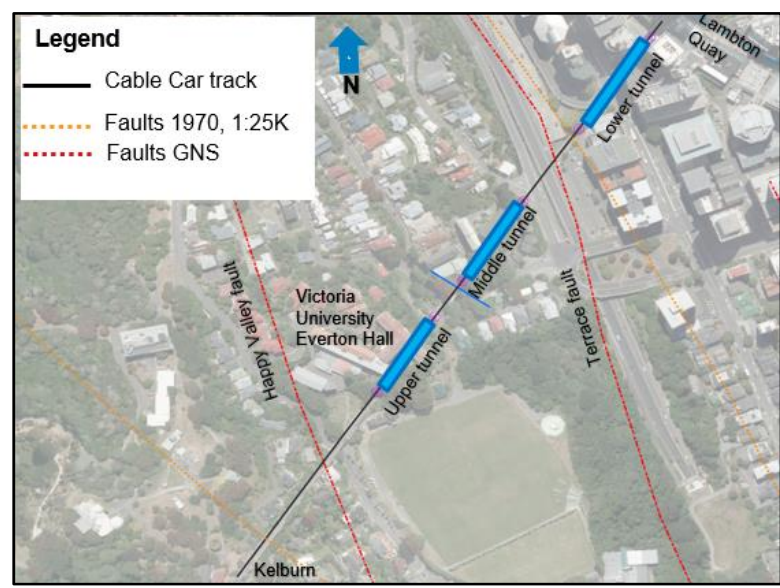

Figure 25: Plan view of the Cable Car line with the three tunnels. Location of Terrace and Happy Valley faults in relation to the Cable Car alignment.

According to the Wellington City District Plan [7], the entire Cable Car Route from Lambton Quay to Upland Road is scheduled as a Heritage Area. This Heritage Area incorporates the carriageway and principal structures of the original 'Kelburn Cable Car', being the three tunnels and three viaducts. The Heritage Area also includes the three stations at Salamanca, Talavera, and Clifton Terraces.

\section{Geology and Seismicity}

The Cable Car alignment is crossed by two faults, the Happy Valley Fault, close to Salamanca Road and the Terrace Fault near the Wellington Urban Motorway (see Figure 25). These faults do not intersect the three tunnels. Previous reports [30] suggest that the Terrace fault is a Class II active fault with a long recurrence interval. Both these faults are mapped as inactive in the geological map of Wellington [2].

The active Wellington Fault is mapped about 500 m northwest from the Kelburn station. A characteristic rupture of the Hutt Valley - Wellington segment of the active Wellington Fault is estimated likely to give rise to an earthquake of magnitude 7.5, with a recurrence interval of 880 years (average) [31], giving a probability of rupture of about $11 \%$ in the next 100 years.

\section{Historical Performance of the Cable Car Tunnels}

Desk study of all information relevant to the tunnels was carried out. The important issues identified, relating to the performance of the tunnels, are:

- Cracking was observed in the late $90 \mathrm{~s}$ along the upper $40 \mathrm{~m}$ of the middle tunnel. Strengthening works comprising shotcrete lining and rock anchors were installed in November 1999 along this section of the middle tunnel. 
- Deformation and cracking were noted in the shotcreted section of the middle tunnel. Convergence monitoring showed ongoing slow-rate movement at this part of the middle tunnel. No appreciable deformations, larger than measurement tolerances, were found along the rest of the tunnels.

- Significant seepages from the brick lining resulting in dissolution and weakening of the outer courses of lime mortar; seepages were more significant in the upper and the lower tunnel.

\section{Basic Principles of the Seismic Assessment}

Wellington Cable Car Limited wanted to better understand the condition of the three tunnels along the Wellington Cable Car line and the need for monitoring and strengthening, with two key objectives: life safety and seismic performance.

The resilience objectives and performance requirements were developed based on principles similar to those used for the other transport tunnels in Wellington city. From an asset management perspective, it was beneficial to consider the criticality of strengthening needs for the different tunnels and portal structures and prioritise and stage any strengthening required.

An initial assessment of the criticality of the different parts of the tunnels was carried out, as part of the desk study, to enable prioritisation for further investigation and assessment. The initial assessment was based on the following criteria:

- Past performance, such as deformation and cracking of the tunnel barrel or portal and associated strengthening or mitigation works.

- Vulnerability of the tunnel portal or barrel to failure under earthquake loading, based on its current condition, overall characteristics, and considering the general performance of tunnels in earthquakes and local conditions.

- Consequences of failure, such as blockage of the track for a substantial period or significant effects on adjacent property and structures.

- Potential cost of reinstatement, in case of failure.

The critically of the different tunnel features was initially assessed as shown below (in order of higher risk and higher priority):

- The upper $40 \mathrm{~m}$ of the middle tunnel barrel (this is described in detail in the following sections).

- The upper portal of the Middle tunnel (MU), which has a height, up to $7 \mathrm{~m}$ (see Figure 26), including the north (left hand-) side wall, which is adjacent to Victoria University buildings uphill from the portal.

- The upper portal of the lower tunnel (LU) and south side wing walls (Figure 27, Figure 28), which are of considerable height ( $\sim 6 \mathrm{~m}$ at the south side), have a shallow thickness of overburden and are adjacent to urban development. Cracking was observed on the portal and side walls.

- The tunnel barrel of the lower tunnel. The overburden of this tunnel along its entire length is currently unclear, because of the substantial adjacent urban development and associated modification of the topography. Rock mass quality along this tunnel could be poorer than the other tunnels, due to its proximity to the Terrace Fault. The adjacent building structures could also pose a risk.

- The other tunnel portals and associated wing walls (UU, UL, ML and LL), which have substantial heights. Their collapse could cause damage to part of the tunnel barrel and blockage of the line for a significant period requiring costly reinstatement. Less critical urban development and structures could be affected.
- The upper tunnel barrel is generally considered to be of lower risk, compared to the other two tunnels, due to the thickness of rock overburden, the good quality of rock mass observed in the nearby outcrops and the relatively good condition of the tunnel lining and lack of signs of distress. These factors make it less prone to damage under earthquake loading.

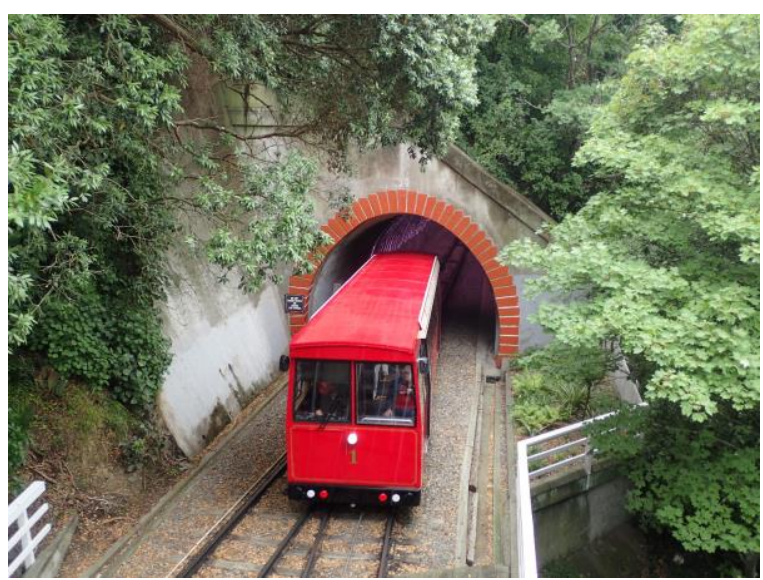

Figure 26: View of upper portal of middle tunnel built near a south dipping slope.

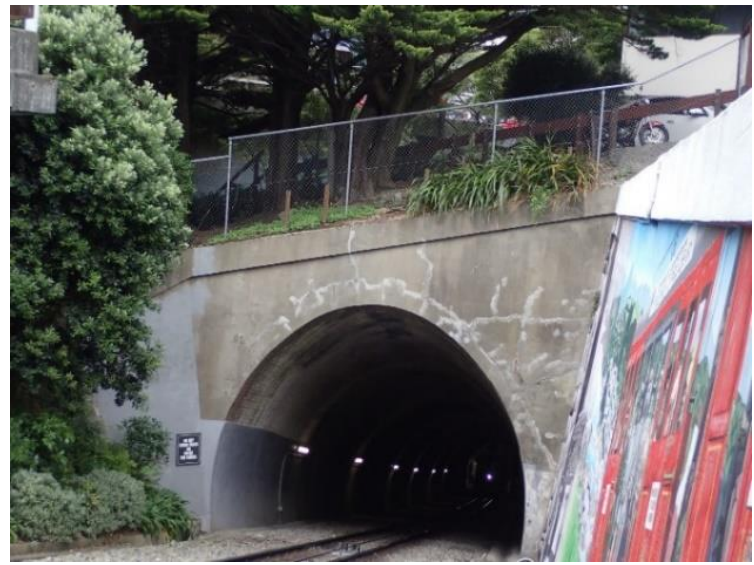

Figure 27: Upper portal of the lower tunnel (LU).

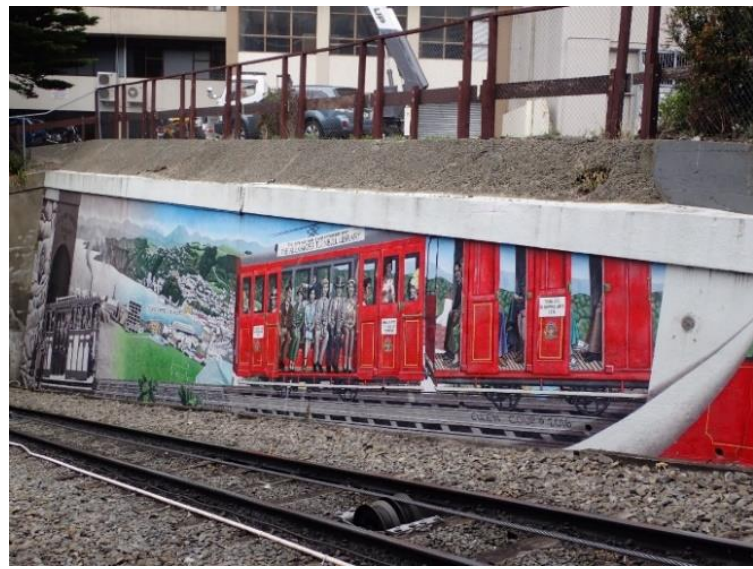

Figure 28: South side wall at the upper portal of the lower tunnel $(L U)$.

\section{Assessment of Seismic Performance}

The Cable Car tunnel portals and wing walls were assessed following the methodology described in the previous sections. The key factors in the assessment and conclusions are summarised in the following sections. 


\section{Tunnel Portals and Wing Walls}

The most likely modes of failure for the unreinforced concrete portal walls were found to be sliding and overturning. Minor cracking could be expected in earthquake shaking with return periods less than 250 years, i.e., with peak ground accelerations of the order of $0.15 \mathrm{~g}$ to $0.3 \mathrm{~g}$. Although there has been no direct record, some of the observed cracking of the portal structures could be attributed to earthquakes with peak ground accelerations of the order of $0.15 \mathrm{~g}$ to $0.2 \mathrm{~g}$ experienced in the past. Such minor damage would be acceptable and easily repairable where this was required.

Displacements in excess of $200 \mathrm{~mm}$ to $300 \mathrm{~mm}$ and associated damage would be expected in a 500-year event (with peak ground accelerations of the order of $0.4 \mathrm{~g}$ to $0.5 \mathrm{~g}$ ), with severe cracking of the walls and dislodgement of some parts. The walls could potentially require replacement leading to disruption of operations for a few months, until repairs and replacement were carried out. Impact on the Cable Car was considered possible, potentially causing limited injuries.

Larger displacements and rotation or collapse of walls cannot be excluded in the 1000-year return period or larger earthquake shaking (for example in a characteristic Wellington fault event) with peak ground accelerations of the order of $0.5 \mathrm{~g}$ to $0.7 \mathrm{~g}$ or greater.

\section{Tunnel Barrels}

The linings of the three tunnels were generally found to be in good condition, even in areas of extensive seepage. The brick was rated as hard and the mortar as hard to very hard [32], based on the measured strengths in excess of $5 \mathrm{MPa}$.

The tunnel barrels (except the upper part of the middle tunnel) were analysed using the method proposed by Wang [11].The brickwork was assumed to behave in a similar fashion to a concrete lining: the premise being that the brickwork will behave homogenously and work predominately in compression, as also proposed by Noble and Kingsland [33]

Exception to the above is the upper $40 \mathrm{~m}$ of the middle tunnel. The Wang [11] approach is inappropriate for this section of the middle tunnel, which is subject to asymmetrical loading, as will be described in the next section.

All other tunnel barrels were found to have adequate performance with only minor and easily repairable damage expected at all levels of earthquakes considered, and therefore no stabilisation measures were considered necessary at this stage.

The ongoing convergence monitoring with the tape extensometer at yearly intervals and regular visual inspections of the condition of the lining were recommended so that any deterioration or deformation can be detected early to allow proactive intervention, if necessary. Records of monitoring and inspections provide benchmark for comparison of the lining performance in case of an earthquake event.

It should be noted that only a cursory assessment was possible for the lower tunnel, as site investigations were not possible given logistical and cost constraints in the built-up location.

\section{Assessment of the Upper Part of the Middle Tunnel}

\section{Background}

The upper $40 \mathrm{~m}$ length and the portal of the middle tunnel are in proximity to a steep slope (Figure 26). The tunnel barrel has low overburden, especially at the south side of the tunnel section, ranging from $2 \mathrm{~m}$ to $3 \mathrm{~m}$ near the portal and up to about $10 \mathrm{~m}$ along the $40 \mathrm{~m}$ section. A $15 \mathrm{~m}$ high, steep, concrete faced cut slope is present at the north (left-hand in Figure 29) side of the portal.

Evidence of distress of the lining of the upper $40 \mathrm{~m}$ length of the Middle tunnel was observed in late 1990's. This consisted of longitudinal cracking of the lining for a length of about $40 \mathrm{~m}$ from the upper portal observed at two locations of the tunnel section, at about 11 and 2 o'clock (see Figure 30).

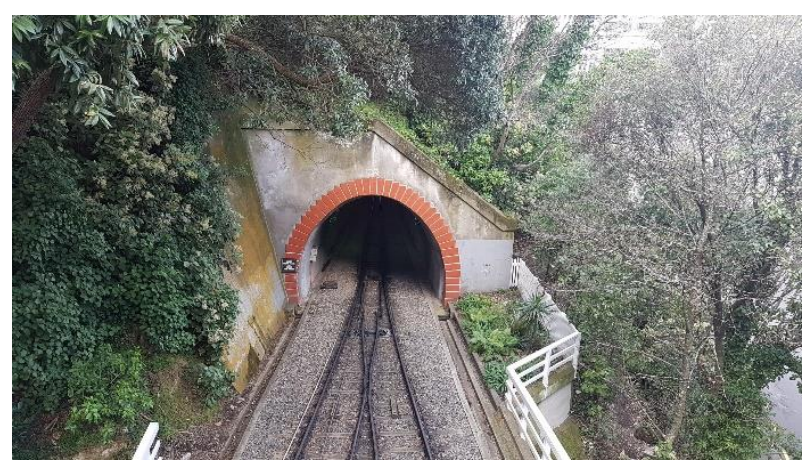

Figure 29: Upper section of middle tunnel near steep slope.

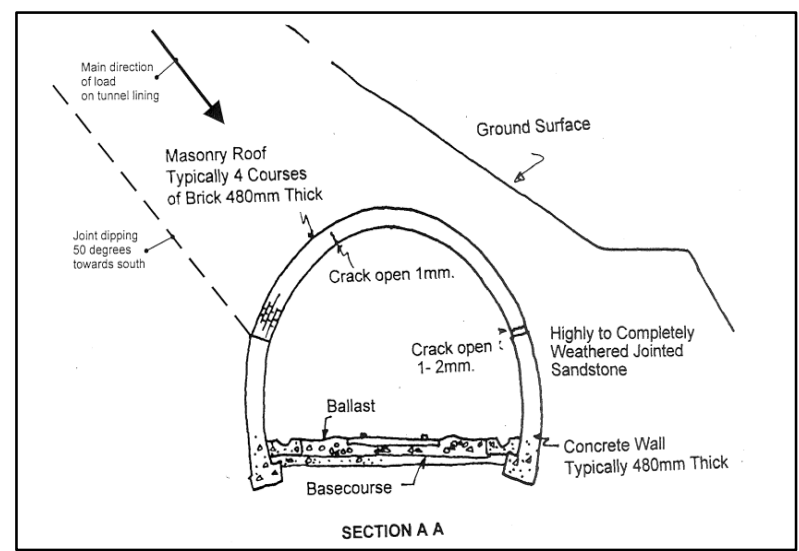

Figure 30: Sketch of the cracking of the lining along the upper $40 \mathrm{~m}$ of the Middle tunnel [34].

The cracking was attributed to asymmetric loading of the tunnel barrel due to its proximity to the slope and potential occasional slope movements (creep). Based on the analysis carried out at the time, it was concluded that the available rock wall at the south side of the tunnel could potentially resist the horizontal loading applied by the uphill slope movements, provided there were no unfavourably oriented rock defects which could cause the rock wall to creep or fail. The slope movement and consequent cracking of the tunnel lining had occurred under static or low to moderate earthquake loading [34].

To mitigate this risk, the following stabilisation measures were installed in 1999 along the upper $40 \mathrm{~m}$ length of the tunnel:

- Shotcrete lining of a typical thickness of $150 \mathrm{~mm}$. The shotcrete was reinforced by steel wire mesh, and steel bars.

- Two rows of rock bolts installed on the north side wall of the tunnel, at heights of $1.5 \mathrm{~m}$ to $2.5 \mathrm{~m}$ from the ground surface. The bolts consisted of $6 \mathrm{~m}$ long, $32 \mathrm{~mm}$ diameter steel bars, fully grouted into $150 \mathrm{~mm}$ diameter holes.

Following the stabilisation works, a convergence monitoring network was installed in the three tunnels in June 2000, and the deformation of the lining has been monitored since, at yearly intervals and following significant earthquakes.

The monitoring results from the upper $40 \mathrm{~m}$ strengthened section of the middle tunnel indicated a slow rate movement of the crown towards the south, as shown in Figure 31 [35]. 
Although the cumulative displacements measured over the years are small, of the order of $2 \mathrm{~mm}$ in total, the trend of tunnel movement towards the south continues to persist and is consistent with the cracking observed prior to 2000 .

A few earthquake events have affected the Wellington region recently, including the magnitude 6.5 Seddon earthquake on 21 July 2013, the magnitude 6.6 Lake Grasmere earthquake on 16 August 2013 and the magnitude 7.8 Kaikoura earthquake on 14 November 2016, and these events were associated with modest ground shaking of up to about $0.2 \mathrm{~g}$ peak ground accelerations in the Kelburn area.

The convergence monitoring following these earthquakes did not show significant displacements at the strengthened section of the Middle tunnel. The ground motions measured on rock or stiff soil sites in Wellington during the above earthquakes were much lower than the peak ground accelerations expected in a 500 -year return-period earthquake shaking of $0.4 \mathrm{~g}-0.5 \mathrm{~g}$ on rock or stiff soil, assessed based on NZS1170.5:2004 [17].

\section{Interpretation of Ground Model and Mechanism of Failure}

The boreholes drilled showed that the rock mass quality is poor to moderate, with distinctive zones of highly fractured shattered and sheared rock.

The downhole acoustic and optical televiewer geophysical surveys carried out in the boreholes confirmed the presence of persistent and systematic unfavourably oriented rock defects, i.e., oriented parallel to the slope. Some of the poor-quality rock zones identified are also unfavourably oriented with respect to the slope. Two defect sub-sets were identified, one shallow dipping ( $<40$ degrees), which may daylight on the slope, and one steeply dipping ( $>40$ degrees) that are not expected to daylight on the slope. The combination of these defect sets forms the potential for a composite failure surface.

The investigations confirmed the initial assessment [34] that inferred the potential presence of poor-quality rock mass and unfavourably oriented rock defects, which exacerbate the slope movements and the effects of asymmetric loading on the tunnel (see Figure 32).
Profile V

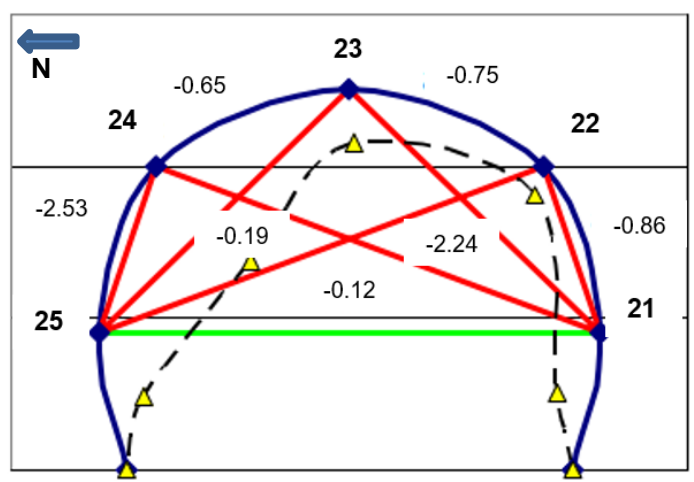

Profile VI

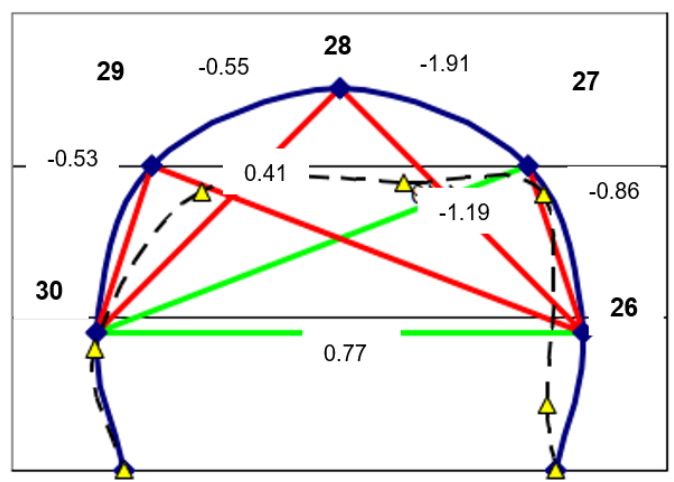

Figure 31: Convergence monitoring profiles V and VI, in the strengthened upper $40 \mathrm{~m}$ of the middle tunnel. Convergence (dashed line) compared to initial (blue line) with movement trend towards the south illustrated (not to scale) [35].

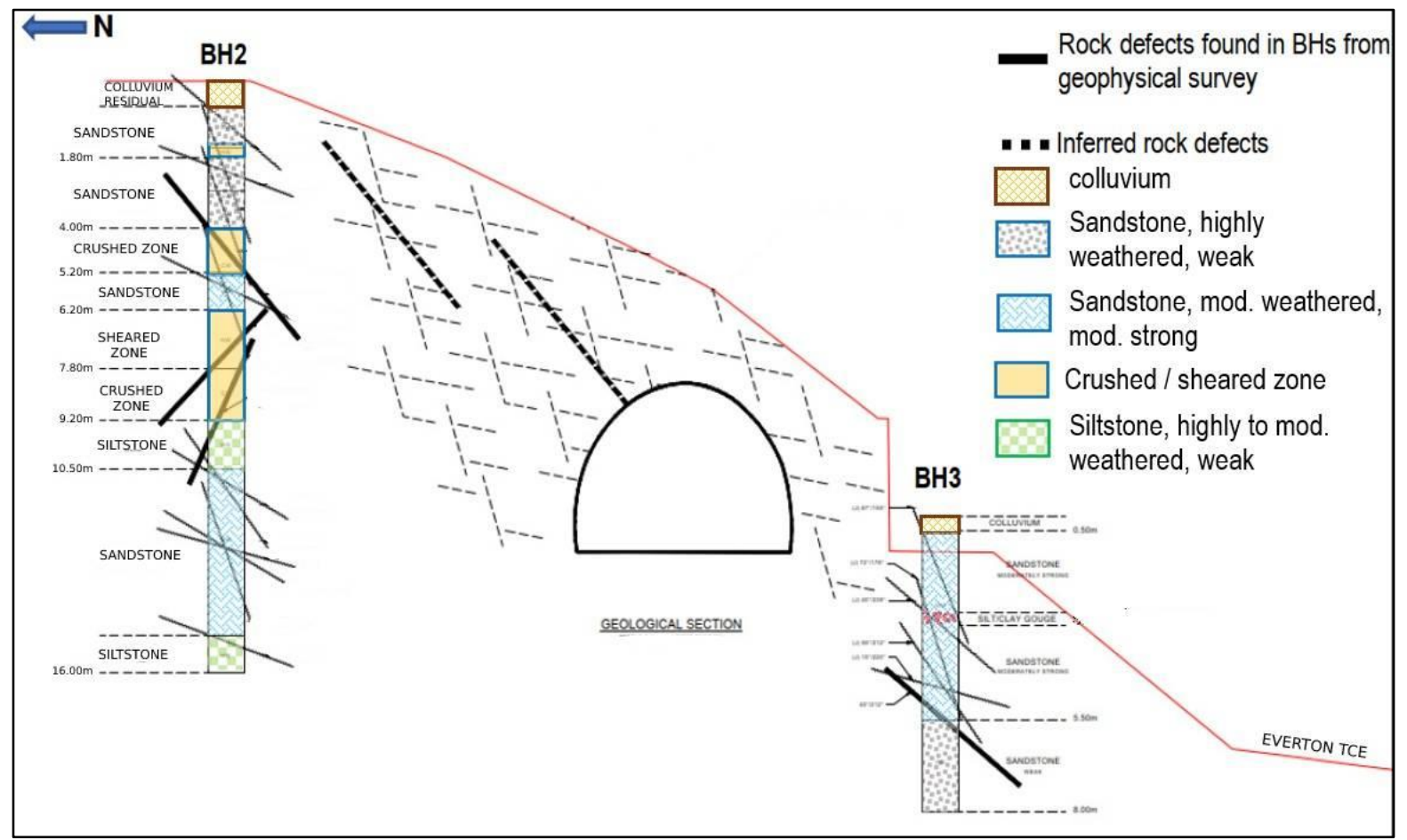

Figure 32: Interpretation of ground model and rock defects affecting the upper $40 \mathrm{~m}$ of the Cable Car middle tunnel. 


\section{Assessment of the Seismic Performance of the Tunnel Barrel}

The stability of the tunnel was assessed by 2-D non-linear seismic ground response analysis using the finite element (FE) software PLAXIS, version 2019. This preliminary analysis was based on limited geotechnical information and was carried out to provide an insight on the likely pattern of deformation of the tunnel barrel and slope under earthquake loading and the effect of the stabilisation measures installed in 1999. The model included the tunnel lining and considered soil structure interaction, however the software can only model non-linearity in the soil, and not in the tunnel lining. Iterations and sensitivity studies were therefore necessary to model the deterioration of the stiffness of the tunnel lining.

The analysis was carried out for the 1: 1000-year return period and Wellington Fault earthquake events. Three recorded ground motions (time-histories) based on the expected magnitudes and ground accelerations that could be expected from rupture of the Ohariu and Wellington Faults were selected for the analysis.

The original brick lining of the tunnel was assumed to resist gravity loads only, while all the loads imposed by the seismic action were assumed to be resisted by the shotcrete lining. The demands on the shotcrete lining were estimated by applying the displacements obtained from the non-linear analysis in PLAXIS, in a structural Microstran model of the lining (as discussed below). These demands were then compared with the capacity of the lining.

The methodology proposed by Wang [11] was used for the derivation of the demand on tunnels consisting of brick lining. For the derivation of the capacity, the MBIE Guidelines Part C [32] were used, considering strengths from the material test results.

It was assumed that the brick structure behaves in a similar fashion to a concrete lining [33], and the brick arch can resist bending moments. Initially (Scenario 1) this would be by tensile capacity of the mortar. Once the mortar cracks (or if the mortar is already pre-cracked) the moment capacity would be a function of the axial compressive force in the arch and the arch's deformed geometry (Scenario 2). It was concluded that under the applied loading and Scenario 1, cracks should not occur in the mortar. Also, under Scenario 2 the estimated deflections of the wall are small enough to provide confidence that the arch would be stable. Conservatively, a default 5\% damping was assumed, although masonry walls are expected to have higher levels of damping. Sensitivity analyses for several input parameters e.g., stiffness of lining and shear wave velocity of the rock were carried out to check the performance.

Conventional 2-D slope stability analysis was also carried out, based on the method of slices, using RocScience SLIDE 2018, ignoring the presence of the tunnel (and lining). This analysis was carried out to provide an understanding of the slope performance and likely modes of failure under the different levels of earthquake events.

Based on the analyses and taking into account damage observed in tunnels near slopes during earthquakes, the most likely seismic performance of the upper $40 \mathrm{~m}$ long section of the Middle tunnel will be deformation of the upper part of the tunnel lining towards the south (downhill) side, as schematically shown in Figure 33. This deformation will cause cracking and spalling of the shotcrete lining. The damage will be more severe with increasing magnitude of the seismic events, with the most severe damage expected for events with return periods equal or larger than 1000 years.

Failure of the steep slope above and at the south (downhill) side of the tunnel is likely during events equal or larger than the 1:500-year event. Such failure will reduce further the thickness of the overburden and of the available rock wall supporting the tunnel along the south (downhill) side of the tunnel. As a result, there will be an increased risk of more significant, and difficult to repair, damage or even collapse of the lining under a subsequent moderate to large event and/or the associated aftershocks.

Based on the results of our assessment, the reinforced shotcrete support installed to strengthen the tunnel section in 1999 is beneficial and has contributed to the stabilisation of the tunnel section under static conditions, and also enhances the seismic performance of the tunnel. The two rows of anchors installed at the lower part of the north tunnel wall, appear to have been installed in good rock, and therefore may not be contributing substantially to the stabilisation of the critical upper part of the tunnel section, or the slope.

Failure of the slope is expected for events larger than the 1:500year event, and this will make the tunnel barrel more vulnerable to subsequent earthquakes or aftershocks. Collapse of parts of the tunnel along this section could occur in this case, especially if the portal is damaged substantially.

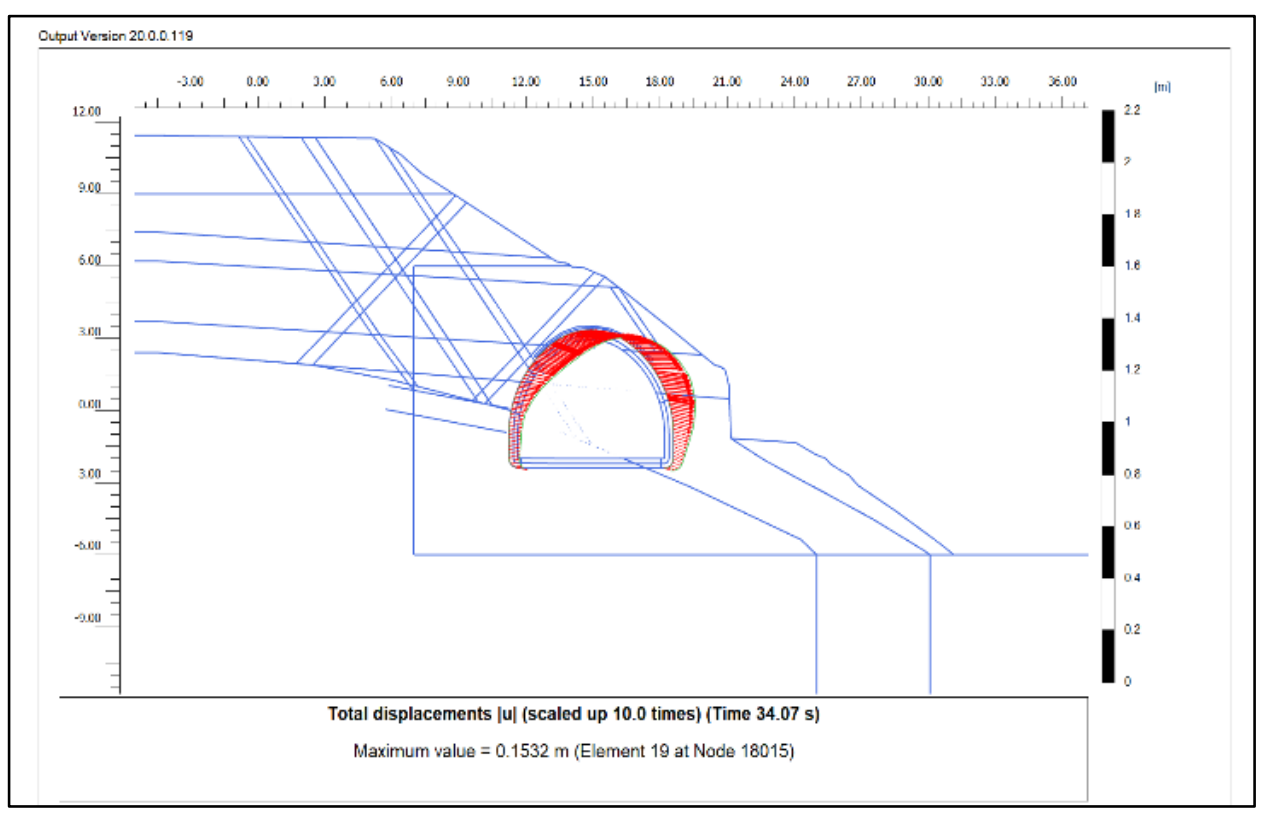

Figure 33: Deformation pattern of tunnel section and of the slope associated with the tunnel under the 1: 1000-year earthquake event, from Plaxis analysis. 
The earthquake performance of the upper $40 \mathrm{~m}$ long section of the Middle tunnel could be enhanced by strengthening the slope above and south of the tunnel with rock anchors. Further strengthening of the tunnel barrel was not considered necessary. The tunnel lining provides sufficient strength to the tunnel barrel, provided that the slope above and at the south side of the tunnel are protected from substantial deformation or failure.

\section{Slope at the North Side of the Tunnel Portal}

A slope about $15 \mathrm{~m}$ high at the north side of the upper portal is protected by an unreinforced concrete facing about $250 \mathrm{~mm}$ to $300 \mathrm{~mm}$ in thickness (Figure 34). The facing was possibly constructed to address relatively shallow failures during or in the early years after construction of the cable car line.

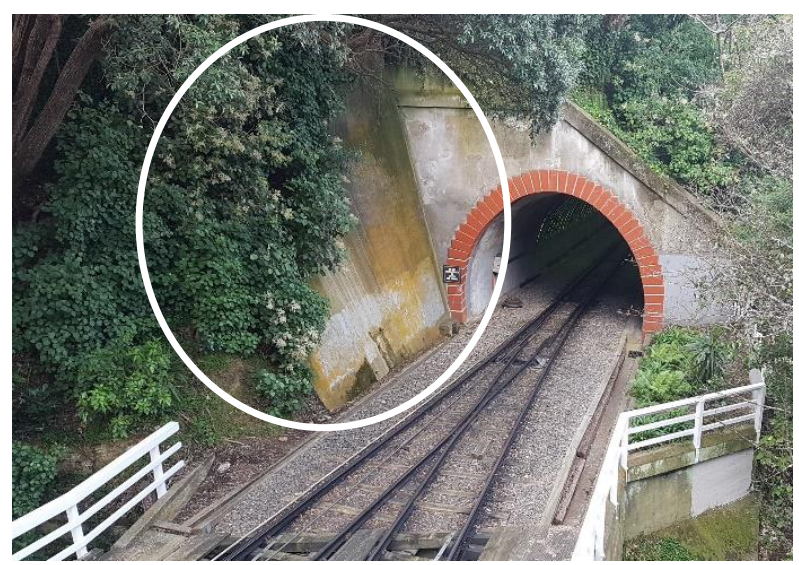

Figure 34: Unreinforced concrete facing on the slope face at the north side of the upper portal of the middle tunnel.

The presence of unfavourably oriented defects has been confirmed from the site investigations above the slope. The stability of the slope under seismic loading has been checked using the RocScience Slide 2018 software for different levels of earthquake shaking. The modes of failure that have been examined include failure through the rock mass, defectcontrolled failures (formed by combination of the unfavourably oriented defects) and combined defect and rock mass failures.

In the 1:25-year to 1:250-year earthquake events, the slope is assessed to experience limited damage consisting of minor cracking of the facing and small slips from the slope above the facing. Under a 1:500-year return period earthquake or larger, damage is expected to consist of severe cracking of the facing or partial collapse, especially of the upper part, where the rock is weaker and the ground shaking is expected to be stronger due to topographical effects. This could cause major disruption to operations for months, and injuries and fatalities are possible, if the Cable Car is severely damaged. Failure of this slope could affect the Victoria University building which is located at a small distance from the top of the slope.

\section{Risk Assessment}

The risk to operations and life safety was assessed for the critical elements of the Cable Car tunnels. Understanding the risk facilitated the prioritisation of actions to manage these risks, and if necessary, the development of strengthening works to enhance resilience. The assessment of the operational risk was primarily qualitative following the Transit New Zealand "Risk Management Process Manual" [36]. The consequences were based on the expected damage to the different elements of the tunnels including costs.

The societal risk to life was assessed quantitatively, based on the proposed methodology by Leroi et al [37]. The societal risk was analysed taking into account factors influencing the likelihood and number of fatalities, such as the annual probability of the earthquake, the likelihood of severe damage of the critical element in that earthquake, the likelihood of the Cable Car being near a critical element of the tunnels during the earthquake considering the total hours of operation per year and the likelihood of fatalities if the Cable Car is affected by damage to the critical elements of the tunnels. A summary of the operational and life safety risk for the critical parts of the Cable Car tunnels is presented in Table 3.

\section{Next Stages}

Based on the assessment, the most critical parts of the Cable Car tunnels, in sequence of criticality are:

1. The upper part of the Middle tunnel including the north side slope, the south facing slope adjacent to the upper $40 \mathrm{~m}$ of the tunnel barrel, and the portal wall;

2. The upper portal of the Lower tunnel (LU);

3. The south side wing wall of the upper portal of the Lower tunnel;

4. The upper portal of the Upper tunnel (UU).

The design and consenting of strengthening of element (1) are already in progress.

Table 3: Summary of operational and life safety risk for the critical parts of the Cable Car tunnels.

\begin{tabular}{|c|c|c|c|c|c|c|c|}
\hline \multirow[b]{2}{*}{ Part of Tunnel } & \multicolumn{2}{|c|}{ 1:250-year event } & \multicolumn{2}{|c|}{ 1:500-year event } & \multicolumn{2}{|c|}{ 1:1000-year event } & \multirow[b]{2}{*}{ Mitigation } \\
\hline & Operational & $\begin{array}{c}\text { Life } \\
\text { safety }\end{array}$ & Operational & Life safety & Operational & Life safety & \\
\hline $\begin{array}{l}\text { Tunnel Barrels (except upper } \\
40 \mathrm{~m} \text { of Middle Tunnel) }\end{array}$ & Low & Low & Low & Low & Moderate & Low & $\begin{array}{l}\text { Accept and } \\
\text { monitor }\end{array}$ \\
\hline Upper portal of Upper tunnel & \multirow{4}{*}{$\begin{array}{l}\text { Low } \\
\text { to Moderate }\end{array}$} & \multirow{4}{*}{ Low } & \multirow{4}{*}{ Moderate } & \multirow{4}{*}{ Low } & \multirow{4}{*}{ High } & \multirow{4}{*}{$\begin{array}{l}\text { Moderate } \\
\text { to high }\end{array}$} & \multirow{5}{*}{$\begin{array}{c}\text { Accept - } \\
\text { Monitor - } \\
\text { Mitigate } \\
\text { where } \\
\text { possible }\end{array}$} \\
\hline $\begin{array}{l}\text { Upper portal of the Lower } \\
\text { tunnel }\end{array}$ & & & & & & & \\
\hline Lower portal south wall & & & & & & & \\
\hline $\begin{array}{l}\text { Upper portal of the Middle } \\
\text { tunnel }\end{array}$ & & & & & & & \\
\hline $\begin{array}{l}\text { Tunnel barrel of the upper } 40 \mathrm{~m} \\
\text { of the Middle tunnel }\end{array}$ & Low & Low & Moderate & Low & High & $\begin{array}{l}\text { Moderate } \\
\text { to High }\end{array}$ & \\
\hline $\begin{array}{l}\text { North side slope of the upper } \\
\text { portal of the Middle tunnel }\end{array}$ & $\begin{array}{l}\text { Low to } \\
\text { Moderate }\end{array}$ & Low & $\begin{array}{l}\text { Moderate to } \\
\text { High }\end{array}$ & Moderate & High & High & $\begin{array}{l}\text { Mitigate } \\
\text { where } \\
\text { possible }\end{array}$ \\
\hline
\end{tabular}


In considering the strengthening programme and priorities, it was recommended to Wellington Cable Car Company to follow an integrated approach, by assessing the seismic performance of other important structures of the Cable Car line that could be damaged and disrupt its operation in a seismic event. This should include seismic assessment of the viaducts and the bridges over the cable car line and adjacent to the lower portals of the Upper and Middle tunnels. This will ensure that the behaviour of the Cable Car line is considered holistically by taking into account the performance of all structures affecting the line's resilience and functionality.

\section{CONCLUSIONS}

The resilience studies of the Wellington region transport network based on a spatial platform developed in GIS and using the resilience metrics developed by Brabhaharan [4] enabled Wellington City Council to develop a long-term strengthening program of routes and structures identified as critical for ensuring accessibility and functionality of the transport network in the region.

Four tunnels owned by Wellington City Council were assessed as vital for the emergency response, recovery and social and economic functionality of Wellington City. These tunnels were constructed in the beginning of the last century and are structures of significant heritage and historical value of the constructed environment in Wellington City.

The earthquake performance of heritage tunnel structures was assessed through understanding the historical information regarding their construction and past performance, appropriate investigations of topography and geometry, lining condition and strength, and ground and groundwater conditions.

Precedent behaviour of tunnels in earthquakes generally shows that underground structures, perform better in earthquakes than surface structures, unless they are adjacent to slopes and / or influenced by slope instability This was confirmed by the assessments carried out for the tunnels discussed in this paper.

The portal structures are more prone to failure under earthquake loading. This was demonstrated by the assessment of the performance of all the tunnels discussed in this paper.

The following elements of the design process were considered instrumental in developing cost effective and acceptable strengthening solutions for the tunnels and thus enabling the works to proceed:

1. The resilience-based design approach, taking into consideration functionality and time for recovery as proposed by Brabhaharan [28]. Critical elements that would close the tunnel for prolonged periods of time were strengthened, whereas vulnerabilities that did not lead to a long period of closure and did not affect the integrity of the main tunnel structures were accepted.

2. A performance-based design approach, i.e. assessing the potential displacements in the different earthquake scenarios and limiting those in the design of mitigation measures. This approach enabled the development of costeffective strengthening solutions that provide a good level of resilience.

3. Architectural design of the strengthening measures, to preserve the existing architectural features of the structures, minimise the effects on their appearance and maintain their heritage status.

\section{ACKNOWLEDGEMENTS}

The authors acknowledge the leadership shown by the Wellington City Council and the Cable Car Company in proactively assessing the resilience of their infrastructure and actions to strengthen them to enhance resilience. The support of WSP for the preparation of the paper is also acknowledged.

\section{REFERENCES}

1 Stirling MW, McVerry GH and Berryman KR (2002). "A new seismic hazard model for New Zealand". Bulletin of the Seismological Society of America, 92(5): 1878-1903. https://doi.org/10.1785/0120010156

2 Begg JG and Johnston MR (2000). "Geology of the Wellington Area: Scale 1:250,000. Lower Hutt”. Institute of Geological \& Nuclear Sciences 1:250,000 Geological Map 10, 64pp. + 1 folded map.

3 Centre for Advanced Engineering (1991). "Lifelines in Earthquakes: Wellington Case Study Summary”. Centre for Advanced Engineering, University of Canterbury.

4 Brabhaharan P (2004). "Systematic Management of the Risks to Transportation Networks from Natural Hazards". 2nd International Symposium on Transportation Network Reliability, 20-24 August, Christchurch, New Zealand.

5 Brabhaharan P (2006). "Recent Advances in Improving the Resilience of Road Networks". Annual Conference of the New Zealand Society for Earthquake Engineering, 10-12 March, Napier.

6 Heritage New Zealand (2020). New Zealand Heritage List/Rārangi Kōrero. https://www.heritage.org.nz/the-list/ (Accessed July 2020)

7 Wellington City Council (2020). ePlan-Our District Plan Online. https://wellington.govt.nz/your-council/plans-policies-andbylaws/district-plan/eplan (Accessed July 2020)

8 New Zealand National Library (2020). PAColl-3366-1 Description: Workmen alongside the entrance to the uncompleted Seatoun tunnel, Wellington, 1905-1906. https://natlib.govt.nz/records/22739250?search\%5Bi\%5D $\% 5$ Bsubject authority id $\% 5 \mathrm{D}=-$ 319003\&search\%5Bpath\%5D=items (Accessed July 2020)

9 New Zealand National Library (2020). PAColl-3366-5 Description: Men at work at the entrance of Seatoun Tunnel, Wellington. Photographed in either 1905 or 1906 by unidentified photographer. https://natlib.govt.nz/records/22739250?search\%5Bi\%5D $\% 5$ Bsubject authority id $\% 5 \mathrm{D}=-$ 319003\&search\%5Bpath\%5D=items (Accessed July 2020)

10 Auckland Libraries (2013). AWNS-19070307-10-3 and AWNS-19070307-11-3. https://www.aucklandlibraries.govt.nz/ (Accessed September 2013)

11 Wang JN (1993). "Seismic Design of Tunnels: A Simple State-of-the-Art Design Approach". WSP/Parsons Brinckerhoff Inc. One Penn Plaza, New York, 147pp.

12 Dowding $\mathrm{CH}$ and Rozen A (1978). "Damage to rock tunnels for earthquake shaking". Journal of the Geotechnical Engineering Division, American Society of Civil Engineers, 104(2): 175-191. https://doi.org/10.1061/AJGEB6.0000580

13 Powers MS, Rosidi D and Kaneshiro J (1998). 'Seismic vulnerability of tunnels and underground structures revisited". Proceedings of the North American Tunnelling Conference, February 1998, Newport Beach, California, USA, p. 243-250, Balkema, Rotterdam. 
14 Wang WL, Wang TT, Su JJ, Lin CH, Seng CR and Huang TH (2001). "Assessment of damages in mountain tunnels due to the Taiwan Chi-Chi earthquake". Tunnelling and Underground Space Technology, 16: 133-150. https://doi.org/10.1016/S0886-7798(01)00047-5

15 Lin CCJ and Chai JF (2008). "Reconnaissance report on the China Wenchuan earthquake May 12". NCREE Newsletter, 3(3): $1-5$

16 Newns WR, Kotze R, Sierra Ballen R and Walters $H$ (2017). "Design and construction of remedial works for rail tunnels impacted by the November 2016 Kaikoura earthquake". 16 ${ }^{\text {th }}$ Australasian Tunnelling Conference, 30 October - 1 November, Sydney, Australia.

17 Standards New Zealand (2004). "Structural Design Actions - Part 5: Earthquake Design Actions". NZS 1170.5:2004. Standards New Zealand, Wellington, 74pp.

18 Wood J (2007). "Earthquake design of rectangular underground structures". Bulletin of the New Zealand Society for Earthquake Engineering, 40(1): 1-6. https://doi.org/10.5459/bnzsee.40.1.1-6

19 Rocscience (2020). Unwedge Software Screenshots. https://www.rocscience.com/software/unwedge (Accessed February 2020)

20 Wood JH and Elms DG (1990). "Seismic design of bridge abutments and retaining walls". Road Research Unit Bulletin, 84(2), 90pp.

21 Brabhaharan P and Saul GJ (2005). "Performance based earthquake risk mitigation of retaining walls at Ngaio Gorge, Wellington". NZ Society for Earthquake Engineering Annual Conference, March 2005, Wairakei, Taupo, NZ.

22 New Zealand Transport Agency (2018). "Bridge Manual Third edition, Amendment 3". SP/M/022. Waka Kotahi, Wellington, 342pp.

23 Brabhaharan P (2006). "Enhanced earthquake design standards for foundations and retaining walls for highway structures". Proceedings of the New Zealand Geotechnical Society and Symposium on Earthquakes and Urban Development, 17-18 February, Nelson, NZ.

24 Brabhaharan P (2007). "Innovation in soil nail design and construction in New Zealand". 10th Australia-New Zealand Conference on Geomechanics. October 2007, Brisbane, Australia.

25 Arumugam S and Brabhaharan P (2016). "Seismic and safety performance assessment and strengthening of tunnels in Wellington". Proceedings of the New Zealand Society for Earthquake Engineering Annual Conference, 1-3 April, Christchurch, NZ, Paper O-44.
26 New Zealand National Library (2020). Reference 1/2050827-F. Description: [Northland Tunnel, Wellington], Taken by an Unidentified Photographer in 1929.

27 Bates W (1984). "Historical Structural Steelwork Handbook". The British Constructional Steelwork Association Limited, UK.

28 Brabhaharan P (2018). "Evolution of resilience-based design of infrastructure". 1 $7^{\text {th }}$ US-Japan-New Zealand Workshop on the Improvement of Structural Engineering and Resilience. 14 November 2018, Queenstown, NZ.

29 Wellington City Council (2020). Cable Car Route. http://www.wellingtoncityheritage.org.nz/areas/8-cablecar-route (Accessed March 2020)

30 Grant-Taylor TL. "Microzoning for Earthquake Effects in Wellington, NZ". New Zealand Department of Scientific and Industrial Research, Wellington, NZ.

31 Van Dissen R, Abbott E, Zinke R, Ninis D, Dolan JF, Little TA, Rhodes EJ, Litchfield NJ and Hatem AE (2020). "Slip rate variations on major strike-slip faults in central New Zealand and potential impacts on hazard estimation". Proceedings of the NZSEE Annual Conference, April 2020, Wellington, NZ.

32 Ministry of Business Innovation and Employment (2018). "Engineering Assessment Guidelines, Part C, Section C8". ISBN: 978-0-478-43367-8, 195pp.

33 Noble A and Kingsland R (2018). "The case for the 'Do Nothing' solution for two heritage-listed brick lined tunnels impacted by motorway construction above". ITA-Annual Meeting and World Tunnel Congress, 21-25 April, Dubai, UAE.

34 Richards L (1999). "Review of Stability Assessment of Wellington Cable Car Tunnel". Laurie Richards Rock Engineering Consultant Report, July 1999, NZ.

35 Underhill JP and Campbell A (2016). "Results of Convergence Monitoring and Visual Inspection to 11 October 2016". Inspection Report, AECOM, NZ.

36 Transit New Zealand (2004). "Risk Management Process Manual". Transit New Zealand, ISBN 0-478-10560-6, Wellington, NZ, 49pp.

37 Leroi E, Bonnard C, Fell R and McInnes R (2005). "Risk assessment and management". Proceedings of the International Conference on Landslide Risk Management, 31 May-3 June, Vancouver, Canada. 